Article

\title{
Development of Natural Gas Fired Combined Cycle Plant for Tri-Generation of Power, Cooling and Clean Water Using Waste Heat Recovery: Techno-Economic Analysis
}

\author{
Gowtham Mohan ${ }^{1,2}$, Sujata Dahal ${ }^{1, *}$, Uday Kumar ${ }^{1,2}$, Andrew Martin ${ }^{2}$ and Hamid Kayal ${ }^{1}$ \\ 1 Swiss Center for Electronics and Microtechnology, CSEM-UAE Innovation Center LLC, \\ Al Jazeera-Al Hamra, PO Box 31208, Ras Al-Khaimah, UAE; \\ E-Mails: uku@csem-uae.com (U.K.); hka@csem-uae.com (H.K.) \\ 2 Department of Energy Technology, KTH Royal Institute of Technology, Stockholm 10044, \\ Sweden; E-Mails: gowtham@kth.se (G.M.); andrew.martin@energy.kth.se (A.M.) \\ * Author to whom correspondence should be addressed; E-Mail: sda@csem-uae.com; \\ Tel.: +971-7-244-6929; Fax: +971-7-244-6951.
}

External Editor: Dieter Brüggemann

Received: 30 June 2014; in revised form: 4 September 2014 / Accepted: 22 September 2014 / Published: 8 October 2014

Abstract: Tri-generation is one of the most efficient ways for maximizing the utilization of available energy. Utilization of waste heat (flue gases) liberated by the Al-Hamra gas turbine power plant is analyzed in this research work for simultaneous production of: (a) electricity by combining steam rankine cycle using heat recovery steam generator (HRSG); (b) clean water by air gap membrane distillation (AGMD) plant; and (c) cooling by single stage vapor absorption chiller (VAC). The flue gases liberated from the gas turbine power cycle is the prime source of energy for the tri-generation system. The heat recovered from condenser of steam cycle and excess heat available at the flue gases are utilized to drive cooling and desalination cycles which are optimized based on the cooling energy demands of the villas. Economic and environmental benefits of the tri-generation system in terms of cost savings and reduction in carbon emissions were analyzed. Energy efficiency of about $82 \%-85 \%$ is achieved by the tri-generation system compared to $50 \%-52 \%$ for combined cycles. Normalized carbon dioxide emission per $\mathrm{MW} \cdot \mathrm{h}$ is reduced by $51.5 \%$ by implementation of waste heat recovery tri-generation system. The tri-generation system has a payback period of 1.38 years with cumulative net present value of $\$ 66$ million over the project life time. 
Keywords: tri-generation; waste heat; steam cycle; air gap membrane distillation; absorption chillers; flue gases; techno-economic

\section{Introduction}

Tri-generation is one of most promising technology integration practice for production of three different outputs with a common primary energy source. Combined heat and power cycle (CHP) would be transformed to poly-generation system by integrating heat driven cooling and desalination cycles in the system. Poly-generation cycles effectively utilize energy and reduce the greenhouse gas emission [1-5]. Combined cooling, heat and power (CCHP) is an extended version of CHP designed for centralized production of cooling, heating and power generation as a large scale system with higher efficiency [6]. In general, power plants in the Middle East and North Africa (MENA) region are combined with desalination plants for recovering heat and producing clean water for meeting domestic needs. However, since decentralized air conditioning systems in the region account for maximum power consumption, tri-generation models with combined production of cooling, clean water and power (CCCWP) would be more beneficial in terms of energy savings and economics.

Previously, several researchers investigated CCHP configurations with gas turbine, steam turbine and organic rankine cycles by combining with absorption, adsorption or desiccant chillers. Ahmadi et al. [7] conducted a detailed thermodynamic modeling of CCHP for providing cooling, hot water and electricity. The system is modeled with combined cycles of gas turbine and organic rankine cycle for power generation, single stage absorption chiller for cooling, and hot water through heat recovery. The system is analyzed in terms of energy efficiency and environmental impact, exergy efficiency of tri-generation system is improved by $20 \%$ compared to conventional CHP. Khaliq [8] simulated a gas turbine based tri-generation system for combined production of power, cooling and heat (process steam). Performance of the system is analyzed for different pressure ratios, turbine inlet temperatures, process heat pressures and evaporator temperatures of absorption chiller. Ahmadi et al. [9] conducted a detailed thermodynamic modeling and simulation of tri-generation system producing power through combined gas turbine and steam turbine cycles. The steam driven absorption chiller utilized to provide cooling, low pressure steam from the heat recovery steam generator (HRSG) is utilized as heat source for absorption chiller and space heating.

Several concepts for the tri-generation system involving reciprocating internal combustion (IC) engines for CCHP purposes were evolved for financial benefit. Temir and Bilge [10] studied the performance of tri-generation systems for production of electricity by reciprocating engines, absorption cooling using saturated steam from the boiler and process heat recovery from exhaust outlets. Huangfu et al. [5] analyzed the performance of micro-scale CCHP for domestic and light commercial applications using reciprocating internal combustion engines, absorption chiller and heat recovery devices. Energy and economic analysis reported a short payback period of 2.97 years. Sun [11] proposed a combined production cycle of electricity by gas engine and cooling by absorption chiller, which provides primary energy savings of $37 \%$ compared to separate conventional power and cooling systems with payback return in 4.52 years. 
Tri-generation or poly-generation systems integrating the desalination technologies for clean water production is investigated by few researchers. Hussain [12] developed a tri-generation system for simultaneous production of cooling, clean water and electricity and analyzed with different technologies to provide cooling and clean water. The system is optimized based on its fuel saving potential. Out of different combinations analyzed, a combination of reverse osmosis, absorption chiller with gas turbine power cycle provides the highest economic benefits. Calise et al. [13] modeled a solar energy based tri-generation for CCCWP applications. Multi-effect desalination unit and vapor absorption chiller are integrated together with hybrid photovoltaic-thermal (PVT) collectors for combined production of cooling, desalination and power. The transient simulations for different operational and design parameters were conducted and optimized in terms of energetic efficiency and economic viability.

In this research work, combined cooling, clean water and power cycle (CCCWP) incorporated with membrane distillation technology for clean water production as a part of a tri-generation system is investigated. Membrane distillation is a promising thermal driven desalination technology, utilizing low grade heat energy for production of clean water [14]. Previously, research was conducted on integration of membrane distillation system for cogeneration applications. Liu [15] analyzed the performance of two different cogeneration systems by integrating membrane distillation modules with a gas engine as combined power and desalination cycles and with vapor compression chiller as a combined cooling and distillation unit. Kullab [16] analyzed the performance of air gap membrane distillation (AGMD) modules with different integration layouts. Burrieza et al. [17] conducted several parametric studies on air gap membrane distillation modules to optimize the performance of the system that produces a maximum distillate flux of $20 \mathrm{~L} / \mathrm{h}$ per module.

\section{System Description}

A tri-generation system is proposed for effective utilization of the waste flue gases liberated by the Al-Hamra gas turbine power plant based in Ras-Al-Khaimah, United Arab Emirates (UAE), as shown in Figure 1. Reheat brayton cycle configuration is utilized in Al-Hamra gas turbine power plant. Air at ambient temperature is compressed and passed to the combustion chamber (CC) for production of super-heated gas. This super-heated gas is further expanded in a series of gas turbines which are connected through reheat chamber $(\mathrm{RH})$ for power production.

Figure 1. (a) Al-Hamra gas power plant; (b) Gas turbine in Al-Hamra power plant.

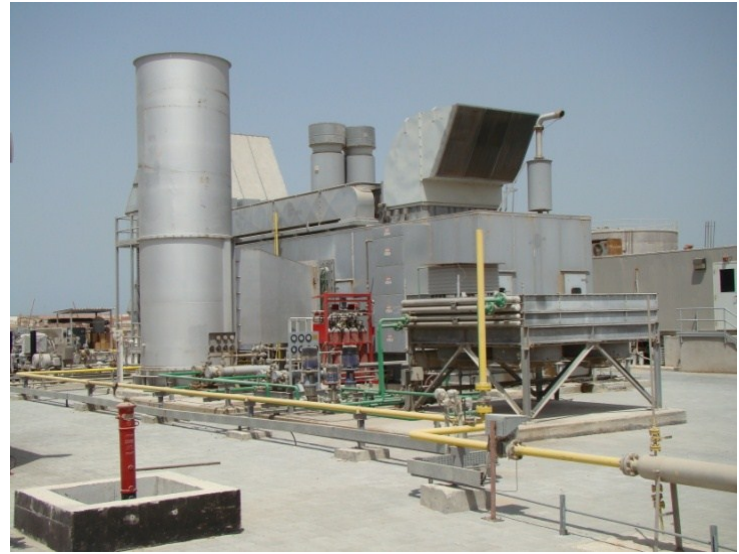

(a)

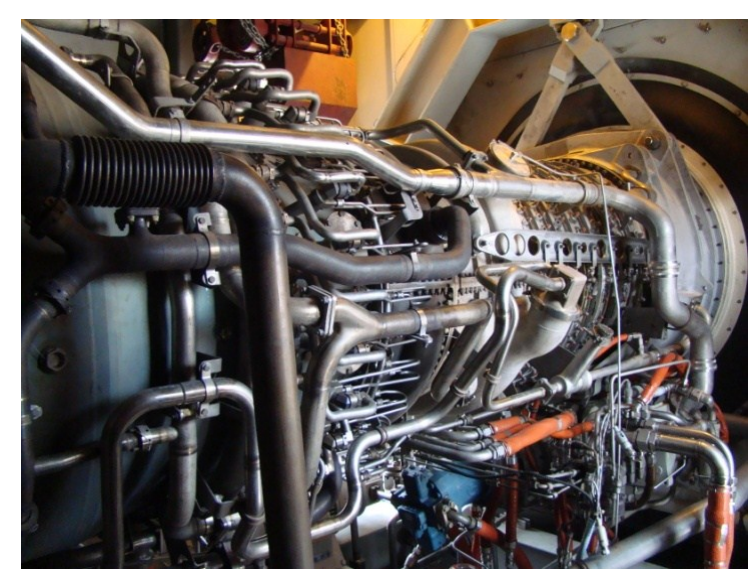

(b) 
The proposed Tri-generation system comprises of steam turbine rankine cycle, single stage $\mathrm{LiBr} / \mathrm{H}_{2} \mathrm{O}$ absorption chiller plant and air gap membrane distillation units. The schematic layout of tri-generation system is shown in Figure 2. The hot flue gases liberated after the expansion in the gas turbine is utilized in the HRSG for production of process steam at higher pressure and temperature, which is further expanded in a steam turbine for production of electricity. The steam is then condensed in a heat recovery system using sea-water. The heat liberated in the heat recovery system is used to drive both the absorption chiller and membrane distillation systems. The condensed steam (feed water) is circulated back to the HRSG using the feed water pump. The stack flue gases leaving the HRSG is utilized to produce additional hot sea water, which is integrated with the supply line of cooling and desalination systems.

Figure 2. Schematic layout of tri-generation system.

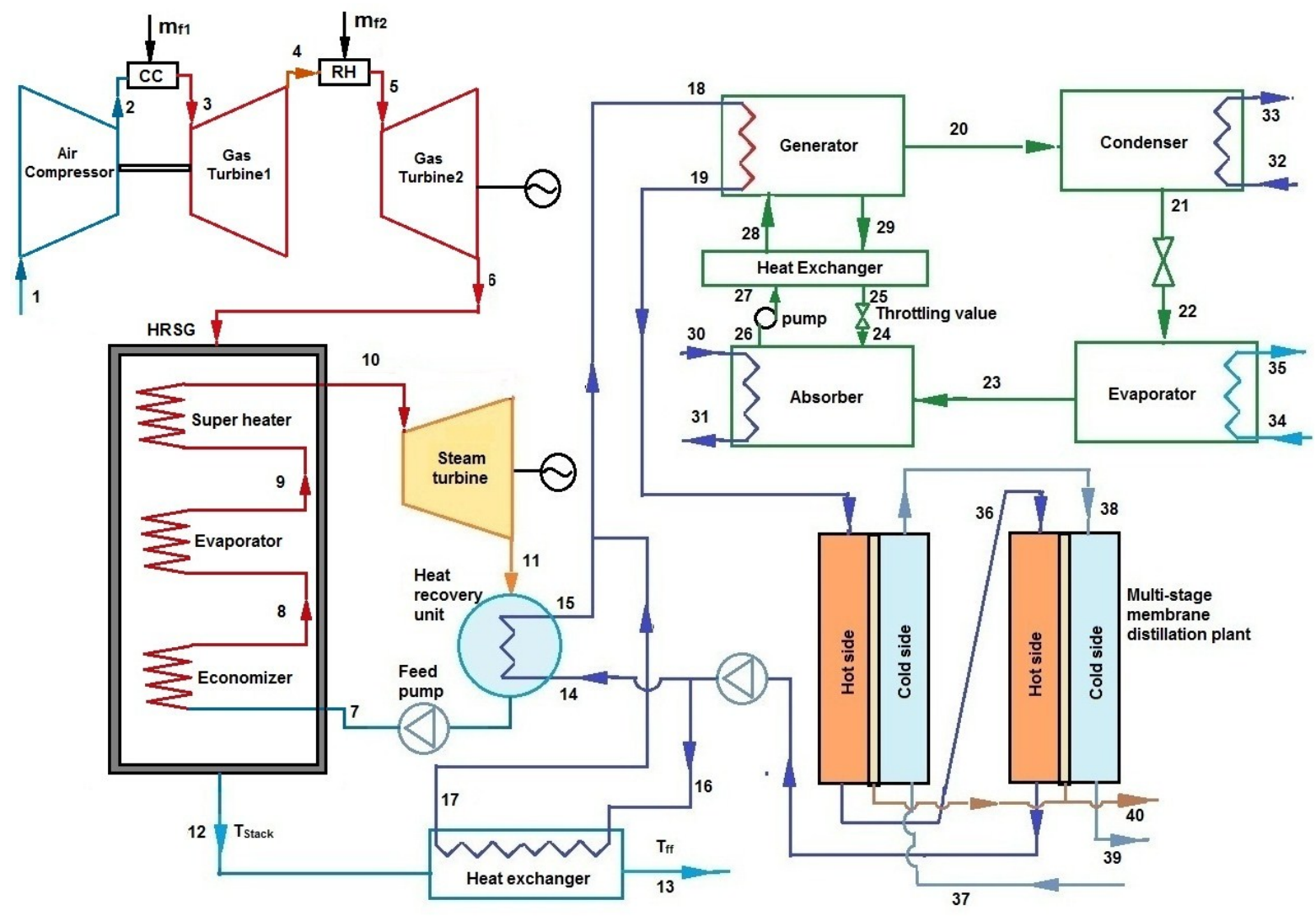

\begin{tabular}{|l|l|l|l|}
\hline No & \multicolumn{1}{|c|}{ Specification } & No & \multicolumn{1}{|c|}{ Specification } \\
\hline 1 & Inlet air entering compressor & 21 & Condensed water exiting condenser \\
\hline 2 & Outlet air from compressor & 22 & Water vapor entering evaporator(VAC) \\
\hline 3 & Combustion gases leaving combustion chamber & 23 & Saturated water entering absorber \\
\hline 4 & Hot gases leaving first gas turbine & 24 & LiBr solution leaving heat exchanger \\
\hline 5 & Combustion gases leaving reheat chamber & 25 & LiBr solution entering absorber \\
\hline 6 & Hot flue gases leaving second gas turbine & 26 & Low pressure LiBr -water mixture \\
\hline 7 & Feed water entering HRSG & 27 & High pressure LiBr- water mixture \\
\hline 8 & Hot water leaving economizer & 28 & Weak solution entering generator \\
\hline 9 & Saturated steam leaving evaporator & 29 & Strong solution leaving generator \\
\hline 10 & Super heated steam entering steam turbine & 30 & Cold sea water entering absorber \\
\hline 11 & Expanded steam entering heat recovery unit & 31 & Sea water leaving absorber \\
\hline 12 & Flue gases leaving HRSG & 32 & Cold sea water entering condenser \\
\hline 13 & Flue gases exiting heat exchanger & 33 & Sea water leaving condenser \\
\hline 14 & Sea water entering heat recovery unit & 34 & Circulation water entering evaporator(VAC) \\
\hline 15 & Hot sea water leaving heat recovery unit & 35 & Chilled water supplied to building \\
\hline 16 & Sea water entering heat exchanger & 36 & Hot sea water supplied to $2^{\text {nd }}$ stage MD \\
\hline 17 & Hot sea water exiting heat exchanger & 37 & Cold sea water supplied to 1st $^{\text {stage }}$ MD \\
\hline 18 & Hot sea water entering generator & 38 & Cold sea water supplied to $2^{\text {nd }}$ stage MD \\
\hline 19 & Hot sea water to $1^{\text {st }}$ stage membrane distiller(MD) & 39 & Sea water leaving cold side of MD \\
\hline 20 & Water vapor entering condenser & 40 & Distillate produced in MD \\
\hline & & & \\
\hline
\end{tabular}




\section{System Modeling}

\subsection{Brayton Cycle}

The reheat Brayton configuration is utilized in Al-Hamra gas turbine power plant as shown in Figure 1. The energy balance of reheat brayton cycle is modeled as follows:

The air at ambient temperature enters the compressor at point 1, the temperature of air $\left(T_{2}\right)$ leaving the compressor is calculated by:

$$
\frac{T_{2}}{T_{1}}=\left(\frac{P r_{2}}{P r_{1}}\right)^{\frac{\gamma-1}{\gamma}}
$$

where $T_{1}$ and $T_{2}$ are the temperatures of air entering and leaving the compressor; $\operatorname{Pr}_{1}$ and $\operatorname{Pr}_{2}$ are the pressures of air before and after compression process; $\gamma$ is the specific heat ratio. Work done by the compressor is calculated by:

$$
W_{\text {Compressor }}=\dot{m}_{\mathrm{a}} C_{\mathrm{p}, \mathrm{air}}\left(T_{2}-T_{1}\right)
$$

where $W_{\text {Compressor }}$ is the work done by the compressor; $\dot{m}_{\mathrm{a}}$ is the mass flow rate of air and $C_{\mathrm{p} \text {,air }}$ is the specific-heat capacity of air. The compressed air is supplied to the $C C$, where the compressed air is combusted with addition of fuel. Energy balance of processes in $C C$ is given by:

$$
\begin{gathered}
Q_{\mathrm{CC}}=\dot{m}_{\mathrm{g}, 1} C_{\mathrm{p}, \text { gas }, 1} T_{3}-\dot{m}_{\mathrm{a}} C_{\mathrm{p}, \mathrm{air}} T_{2} \\
Q_{\mathrm{CC}}=\dot{m}_{\mathrm{f}, 1} \cdot L H V
\end{gathered}
$$

where $Q_{\mathrm{CC}}$ is the heat energy supplied by the combustion chamber; $\dot{m}_{\mathrm{g}, 1}$ is the mass of gas leaving the combustion chamber; $T_{3}$ is the temperature of gas leaving the combustion chamber; $\dot{m}_{\mathrm{f}, 1}$ is the mass flow rate of fuel supplied to $C C$ and $L H V$ is the lower heat-value of fuel. The gas at super-heated temperature $\left(T_{3}\right)$ is expanded in the first gas turbine,

$$
Q_{\mathrm{gt}, 1}=\dot{m}_{\mathrm{g}, 1} C_{\mathrm{p}, \mathrm{gas}}\left(T_{3}-T_{4}\right)
$$

where $Q_{\mathrm{gt}, 1}$ is the energy extracted from the first gas turbine and $T_{4}$ is the temperature of flue gases leaving the gas turbine. The flue gases liberated from the first gas turbine is further combusted in reheat chamber, energy balance in the reheat chamber is:

$$
\begin{gathered}
Q_{\mathrm{RH}}=\dot{m}_{\mathrm{g}, 2} C_{\mathrm{p}, \mathrm{gas}, 2} T_{5}-\dot{m}_{\mathrm{g}, 1} C_{\mathrm{p}, \mathrm{gas}, 1} T_{4} \\
Q_{\mathrm{RH}}=\dot{m}_{\mathrm{f}, 2} \cdot L H V
\end{gathered}
$$

$Q_{\mathrm{RH}}$ is the heat energy supplied by the reheat chamber; $\dot{m}_{\mathrm{g}, 2}$ is the mass of gas leaving the reheat section; $T_{5}$ is the temperature of gas leaving the reheat section and $\dot{m}_{\mathrm{f}, 2}$ is the mass flow rate of fuel supplied to $R H$. The reheated gas is expanded in the second gas turbine:

$$
Q_{\mathrm{gt}, 2}=\dot{m}_{\mathrm{g}, 2} C_{\mathrm{p}, \mathrm{gas}, 2}\left(T_{5}-T_{6}\right)
$$

where $T_{6}$ is the temperature of flue gases leaving the system, which is utilized as the heat source for driving the tri-generation system. 


\subsection{Steam Cycle}

\subsubsection{Heat Recovery Steam Generator (HRSG)}

In the tri-generation cycle, single pressure HRSG with economizer, evaporator and super heater sections are utilized for the generation of super-heated process steam. The temperature profile of HRSG is shown in Figure 3. The pinch point is the temperature difference between the gas and water (at saturation temperature) at the point of entry into the evaporator. Pinch point plays a vital role in energy modeling of HRSG. The approach temperature between the economizer exit and entry of evaporator is considered as constant in the modeling. Approach temperature depends on the tube layout of economizer circuit.

Figure 3. Temperature-Entropy ( $T-S)$ diagram of Heat Recovery Steam Generator (HRSG).

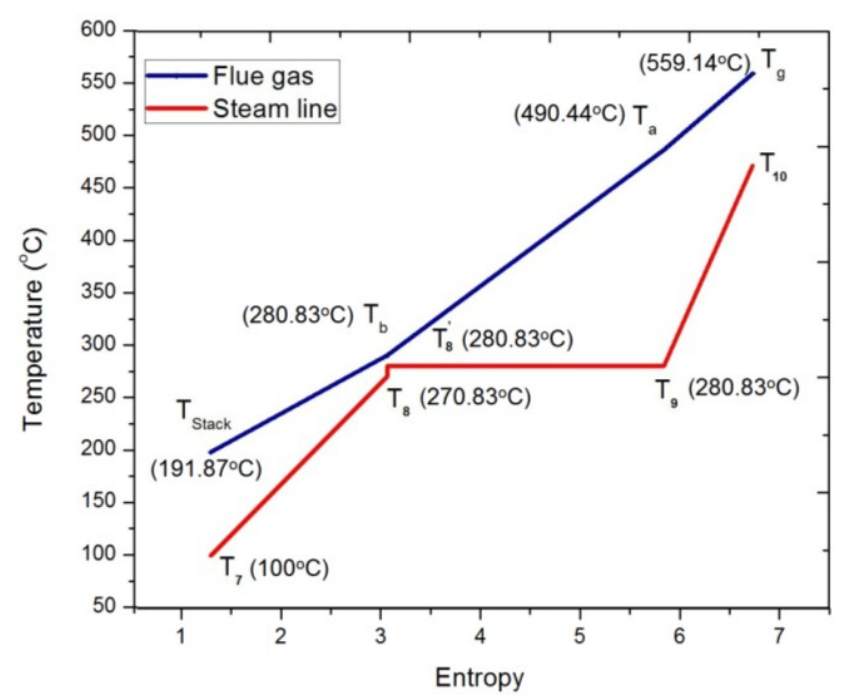

Energy balance of individual sections of HRSG is modeled. Using pinch point temperature difference, energy balance of the evaporator is analyzed:

$$
\dot{m}_{\mathrm{w}}\left(h_{9}-h_{8^{\prime}}\right)=\dot{m}_{g} C_{\mathrm{P}, \mathrm{g}}\left(T_{\mathrm{a}}-T_{\mathrm{b}}\right)
$$

where $\dot{m}_{w}$ is the mass flow rate of steam generation line; $\dot{m}_{\mathrm{g}}$ is the mass flow rate of hot flue gases; $C_{\mathrm{P}, \mathrm{g}}$ is the heat transfer coefficient of hot flue gases; $h_{8}$, and $h_{9}$ are the enthalpy of the saturated water and steam, respectively; $T_{\mathrm{a}}$ is the temperature of gas entering the evaporator and $T_{\mathrm{b}}$ is the temperature of gas leaving the evaporator. Energy balance of the super heater is shown below:

$$
\dot{m}_{\mathrm{w}}\left(h_{10}-h_{9}\right)=\dot{m}_{\mathrm{g}} C_{\mathrm{P}, \mathrm{g}}\left(T_{6}-T_{\mathrm{a}}\right)
$$

where $h_{10}$ is the enthalpy of the super-heated steam and $T_{6}$ is the temperature of hot flue gas entering the HRSG. Energy balance of the economizer can be shown as:

$$
\dot{m}_{\mathrm{w}}\left(h_{8}-h_{7}\right)=\dot{m}_{\mathrm{g}} C_{\mathrm{P}, \mathrm{g}}\left(T_{\mathrm{b}}-T_{\text {Stack }}\right)
$$

where $h_{7}$ and $h_{8}$ are the enthalpies of the hot water at the entry and exit of economizer and $T_{\text {Stack }}$ is the stack temperature of flue gases leaving the HRSG. 


\subsubsection{Steam Turbine}

High pressure super-heated steam generated in the HRSG is expanded to ambient pressure using a steam turbine. Energy extracted $\left(W_{\mathrm{ST}}\right)$ in the turbine is calculated as follows:

$$
W_{\mathrm{ST}}=\dot{m}_{\mathrm{w}}\left(h_{9}-h_{10}\right)
$$

where $h_{10}$ is the enthalpy of steam leaving the turbine.

\subsubsection{Heat Recovery System}

The steam liberated from the steam turbine is condensed in a heat recovery system, where steam exchanges heat with sea water to drive both the absorption chiller and membrane distillation unit. Additionally, a part of heat energy is recovered by sea water from the stack flue gases. It is integrated with the supply line of refrigeration and desalination modules. Energy balance of the heat recovery system is given by:

$$
\begin{gathered}
Q_{\text {extract }}=\dot{m}_{\mathrm{w}}\left(h_{11}-h_{7}\right)+\dot{m}_{\mathrm{g}} C_{\mathrm{P}, \mathrm{g}}\left(T_{\mathrm{stack}}-T_{\mathrm{ff}}\right) \\
Q_{\text {extract }}=\dot{m}_{\mathrm{SW}} C_{\mathrm{P}, \mathrm{SW}}\left(T_{\mathrm{SW}, \text { out }}-T_{\mathrm{SW}, \text { in }}\right)
\end{gathered}
$$

where $Q_{\text {extract }}$ is the heat extracted from the steam; $h_{7}$ is the enthalpy of water leaving the condenser at $100{ }^{\circ} \mathrm{C} ; T_{\mathrm{ff}}$ is the temperature of flue gas leaving the heat exchanger; $\dot{m}_{\mathrm{SW}}$ is the mass flow rate of sea water; $C_{\mathrm{P}, \mathrm{SW}}$ is specific heat capacities; $T_{\mathrm{Sw} \text {,in }}$ and $T_{\mathrm{SW} \text {,out }}$ are the temperatures of sea water entering and leaving the heat recovery system. The area of heat recovery system is determined by:

$$
A_{\mathrm{HRS}}=\frac{Q_{\text {extract }}}{U_{\mathrm{HRS}} \times \Delta T_{\mathrm{LMTD}}}
$$

where $A_{\mathrm{HRS}}$ is the area of the heat recovery system; $U_{\mathrm{HRS}}$ is the overall heat transfer coefficient of the heat recovery system and $\Delta T_{\mathrm{LMTD}}$ is the logarithmic mean temperature difference.

\subsection{Absorption Chiller}

Absorption chiller considered in the tri-generation system is $\mathrm{LiBr} / \mathrm{H}_{2} \mathrm{O}$ vapor absorption chiller. The system is designed to provide district cooling to multiple duplex-villas in the region of Al-Hamra, UAE as shown in Figure 4 [18]. The system is optimized based on cooling load requirements of villas. Energy balance of vapor absorption chiller is calculated as:

$$
\begin{gathered}
Q_{\mathrm{ch}}=\dot{m}_{\mathrm{ac}, \mathrm{ch}} C_{\mathrm{p}} \Delta T_{\mathrm{ac}, \mathrm{ch}} \\
Q_{\mathrm{gen}}=\dot{m}_{\mathrm{SW}} C_{\mathrm{P}, \mathrm{SW}} \Delta T_{\mathrm{ac}, \mathrm{h}} \\
C O P_{\mathrm{T}}=\frac{Q_{\mathrm{Ch}}}{Q_{\mathrm{gen}}}
\end{gathered}
$$

where $Q_{\text {ch }}$ is the chilling capacity of absorption chiller; $Q_{\text {gen }}$ is the heat supplied the generator of absorption chiller; $\dot{m}_{\mathrm{ac}, \mathrm{ch}}$ and $\dot{m}_{S W}$ are the mass flow rates of chilled water and hot water flowing through the absorption chiller; $\Delta T_{\mathrm{ac}, \mathrm{ch}}$ is the temperature difference of inlet and outlet of chilled-water circuit and $\Delta T_{\mathrm{ac}, \mathrm{h}}$ is the temperature difference between hot water inlet and outlet of the generator. 
Figure 4. Duplex villa in Al hamra.

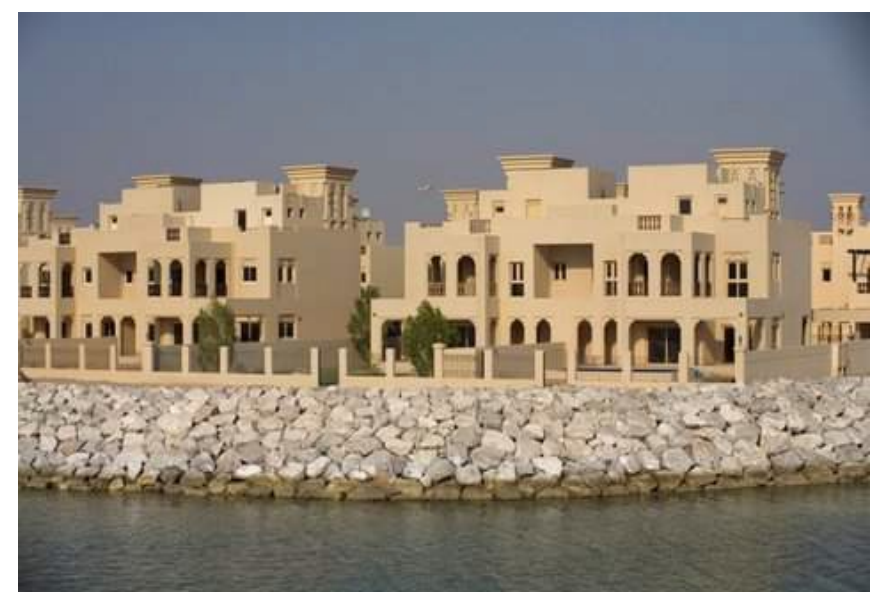

\subsection{Membrane Distillation}

In the tri-generation system, membrane distillation module with air-gap configuration is considered for clean water production. The membrane modules considered for the analysis is manufactured by Scarab Development AB, Stockholm, Sweden. The hot sea water leaving the generator of the absorption chiller is supplied to a large number of multi-effect membrane distillation modules connected in parallel. Technical specifications of membrane distillation module are shown in Table 1.

Table 1. Technical specifications of membrane module [16]. Copyright 2011 KTH Royal Institute of Technology.

\begin{tabular}{ccc}
\hline No. & Specification & Value \\
\hline 1 & Membrane area & $2.8 \mathrm{~m}^{2}$ \\
2 & Porosity $(\phi)$ & 0.8 \\
3 & Membrane thickness $(b)$ & $0.2 \mathrm{~mm}$ \\
4 & Air gap width $(L)$ & $1 \mathrm{~mm}$ \\
5 & Height of the module & $730 \mathrm{~mm}$ \\
6 & Width of the module & $630 \mathrm{~mm}$ \\
7 & Thickness of the module & $175 \mathrm{~mm}$ \\
\hline
\end{tabular}

The mass and energy balance of membrane modules are calculated based on experimental equations developed through series of experiments conducted in Nyköping, Sweden [15]. The mass flow rate of sea water supplied to hot and cold side is optimally selected as $1200 \mathrm{~kg} / \mathrm{h}$ based on detailed experimental campaign [15]. The experimental equations for mass and energy flux are derived in function of porosity, air gap thickness, membrane thickness and inlet temperatures of hot and cold fluids. These equations provide better approximations $[15,16]$.

$$
M_{\mathrm{dis}}=4.1 \times 10^{-3} \times \frac{1}{\left[b /\left(\phi \times \sqrt{T_{\mathrm{MD}, \mathrm{H}, \mathrm{in}}}\right)\right]+\left(L / \sqrt{T_{\mathrm{MD}, \mathrm{C}, \mathrm{in}}}\right)} \times \ln \frac{\left(1-X_{\mathrm{c}}\right)}{\left(1-X_{\mathrm{h}}\right)}
$$

where $M_{\text {dis }}$ is the mass of distillate produced per hour for unit surface area of the membrane; $b$ is the thickness of the membrane; $L$ is the air gap distance; $X_{\mathrm{c}}$ and $X_{\mathrm{h}}$ are the mole fraction of water vapor on at 
the condensation and evaporation surfaces; $T_{\mathrm{MD}, \mathrm{H}, \mathrm{in},} T_{\mathrm{MD}, \mathrm{H}, \text { out }} T_{\mathrm{MD}, \mathrm{C} \text {,in }}$ and $T_{\mathrm{MD} \text {, C,out }}$ are the temperature of hot water inlet, hot water outlet, cold water inlet and cold water outlet of the AGMD:

$$
\begin{gathered}
X_{\mathrm{c}}=\frac{p_{i, \mathrm{c}}}{P} \\
X_{\mathrm{h}}=\frac{p_{i, \mathrm{~h}}}{P} \\
p_{i, \mathrm{c}}=e^{\left(\frac{12.03-4025}{\left.T_{\mathrm{MD}, \mathrm{C}, \mathrm{in}+235}\right)}\right.} \\
p_{i, \mathrm{~h}}=e^{\left(\frac{12.03-4025}{T_{\mathrm{MD}, \mathrm{H}, \mathrm{in}}+235}\right)}
\end{gathered}
$$

where $p_{i, \mathrm{~h}}$ and $p_{i, \mathrm{c}}$ are the partial pressures of the vapor at hot and cold sides; $P$ is the total pressure, Energy flux $\left(E_{\mathrm{MD}}\right)$ of the AGMD is calculated by:

$$
\begin{gathered}
E_{\mathrm{MD}}=\frac{1.5 \times 10^{-3} \times\left(T_{\mathrm{MD}, \mathrm{H}, \mathrm{in}}-T_{\mathrm{MD}, \mathrm{C}, \mathrm{in}}\right)}{\left(b /\left(\gamma \phi \sqrt{T_{M D, H, \mathrm{in}}}\right)+\left(L / \sqrt{T_{M D, C, \mathrm{in}}}\right)\right.} \times\left(1+1.41 \times \ln \frac{\left(1-X_{\mathrm{c}}\right)}{\left(1-X_{\mathrm{h}}\right)}\right) \\
\times \frac{b /\left(\gamma \phi \sqrt{T_{\mathrm{MD}, \mathrm{H}, \mathrm{in}}}\right)}{\left(b / \phi \sqrt{T_{\mathrm{MD}, \mathrm{H}, \mathrm{in}}}\right)+\left(L / \sqrt{T_{\mathrm{MD}, \mathrm{C}, \mathrm{in}}}\right)} \\
\gamma=\frac{k_{\mathrm{membrane}}}{\phi \times k_{\mathrm{air}}}
\end{gathered}
$$

$\phi$ is the porosity of the membrane material; $k_{\text {air }}$ is the thermal conductivity of air; $k_{\text {membrane }}$ is based on material type. The useful energy consumed by the membrane distillation is calculated as:

$$
Q_{\text {dis }}=M_{\text {dis }}\left(\lambda_{\mathrm{L}}\right)
$$

where $Q_{\text {dis }}$ is the useful energy required for evaporation of vapor; $\lambda_{\mathrm{L}}$ is the latent heat of evaporation.

\subsection{Energy Efficiency}

Energy efficiency is the ratio of useful energy produced by the system to the amount of energy supplied to the system. In this study, efficiency of gas turbine power plant (existing), combined cycle and tri-generation (power, cooling and desalination) are individually analyzed:

$$
\begin{gathered}
\eta_{\mathrm{GT}}=\frac{W_{\mathrm{GT}}}{\dot{m}_{\mathrm{f}} \times \mathrm{LHV}} \\
\eta_{C C}=\frac{W_{\mathrm{GT}}+W_{\mathrm{ST}}}{\dot{m}_{\mathrm{f}} \times \mathrm{LHV}} \\
\eta_{\mathrm{Tri}}=\frac{W_{\mathrm{GT}}+W_{\mathrm{ST}}+Q_{\mathrm{ch}}+Q_{\mathrm{dis}}}{\dot{m}_{\mathrm{f}} \times \mathrm{LHV}}
\end{gathered}
$$

where $W_{\text {GT }}$ and $W_{\text {ST }}$ are the work done by the gas turbine and steam turbine; $\dot{m}_{\mathrm{f}}$ is the mass flow rate of the fuel; LHV is the lower heating value; $Q_{\text {ch }}$ is the chilled energy produced in the absorption chiller and $Q_{\text {dis }}$ is the useful energy utilized by membrane distillation unit. 


\section{Results and Discussion}

Thermodynamic modeling and optimization of complete tri-generation system for cooling, desalination and hot water is analyzed and discussed in this section.

\subsection{Brayton Cycle}

The gas turbine cycle is numerically modeled with data and parameters provided by the Al-Hamra gas turbine power plant [19]. The reheat-brayton cycle operated in the Al-Hamra power plant is optimized to maintain a constant temperature of $1097 \mathrm{~K}$, at the inlet conditions of both the gas turbines irrespective of the air intake temperature. The pressure ratio and the rate of air intake at the compressor as well as the rate of fuel intake in the combustion and reheat chambers were optimized to achieve $1097 \mathrm{~K}$ at the inlet of gas turbines. The mean operational parameters of gas turbine are shown in Table 2. The performance of brayton cycle is analyzed for varying the air inlet temperatures as shown in Figure 5.

Table 2. Technical specifications of gas turbine power plant.

\begin{tabular}{cc}
\hline Description & Parameters \\
\hline Gas turbine model (GE-manufacturer) & Model: LM2500 PE, Avio, Italy \\
Gas turbine inlet temperature & $824^{\circ} \mathrm{C}$ \\
Mean intake air temperature & $35{ }^{\circ} \mathrm{C}$ \\
Mean exhaust gas flow & $64.1 \mathrm{~kg} / \mathrm{s}$ \\
Mean exhaust gas temperature & $550^{\circ} \mathrm{C}$ \\
Lower Heating Value & $47,000 \mathrm{~kJ} / \mathrm{kg}$ \\
\hline
\end{tabular}

Figure 5. Performance of gas power cycle for varying inlet temperatures.

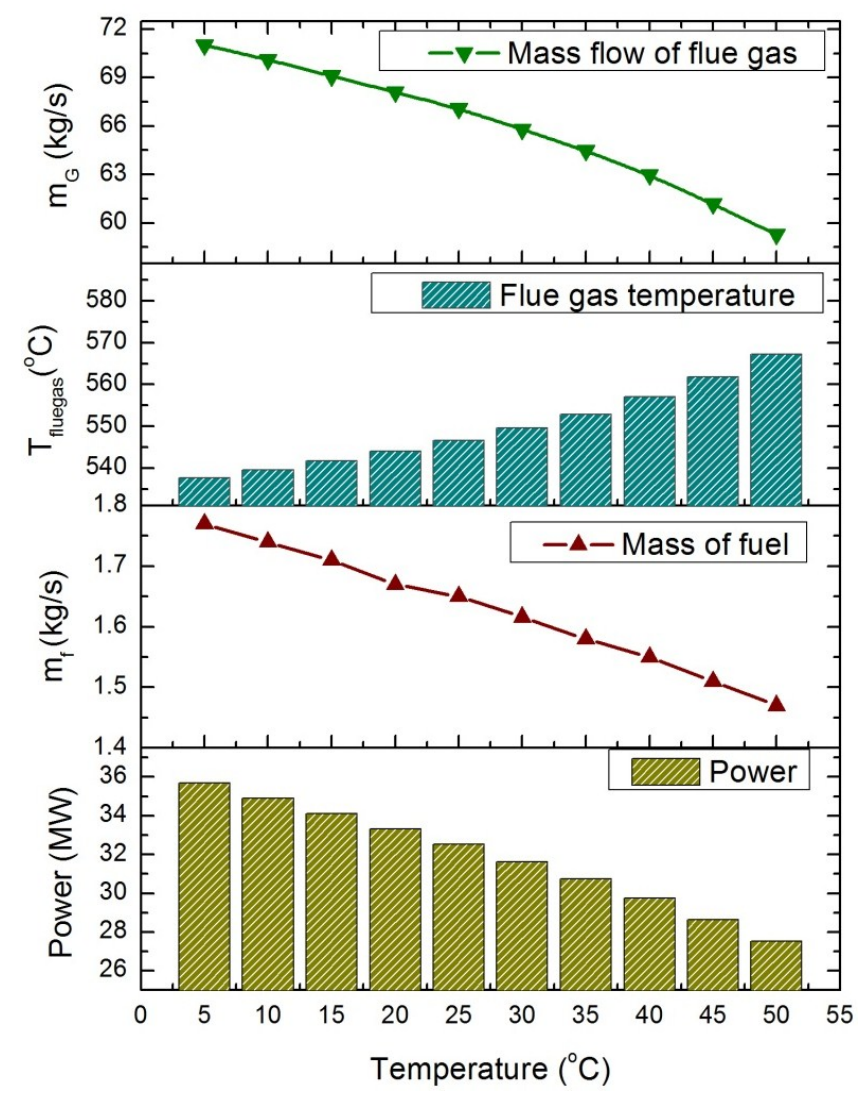


The air intake temperature is an influential factor in augmenting the performance of gas turbine cycle. Reduction in the air intake temperature can drastically increase the gas turbine power output. However, on the contrary, reduction in air intake temperature increases the rate of fuel consumption in order to provide the desired operating temperature at the inlet of gas turbine. The mass of fuel consumption is derived based on the energy balances at the combustion and reheat chambers. Increase in fuel consumption has direct impact on the exhaust gas flow rate. The temperature of flue gases liberated from the gas turbine rises with the increase in air intake temperature. This results in reduction of pressures ratios with increase in air intake temperature to provide designed gas turbine inlet temperature.

The annual performance of the gas cycle in term of electricity generation and mass of fuel consumption is shown in Figure 6. As discussed earlier, the air inlet temperature is the influential parameter in the performance of the gas cycle. The electrical performance of the gas cycle reduces by $10 \%$ in peak summer months. Maximum productivity of $34 \mathrm{MW}$ is achieved in winter months. Annual variations in the amount of flue gases produced and its temperatures are shown in Figure 6. In summer, the temperature of flue gases maximizes as the pressure ratio is reduced at higher air intake temperatures. The mass flow rate of exhaust gases liberated from the gas cycle is reduced in summer due to reduction in the amount of fuel consumption and rate of air intake.

Figure 6. Annual variations in power production, rate of fuel intake and exhaust gas parameters in gas cycle.

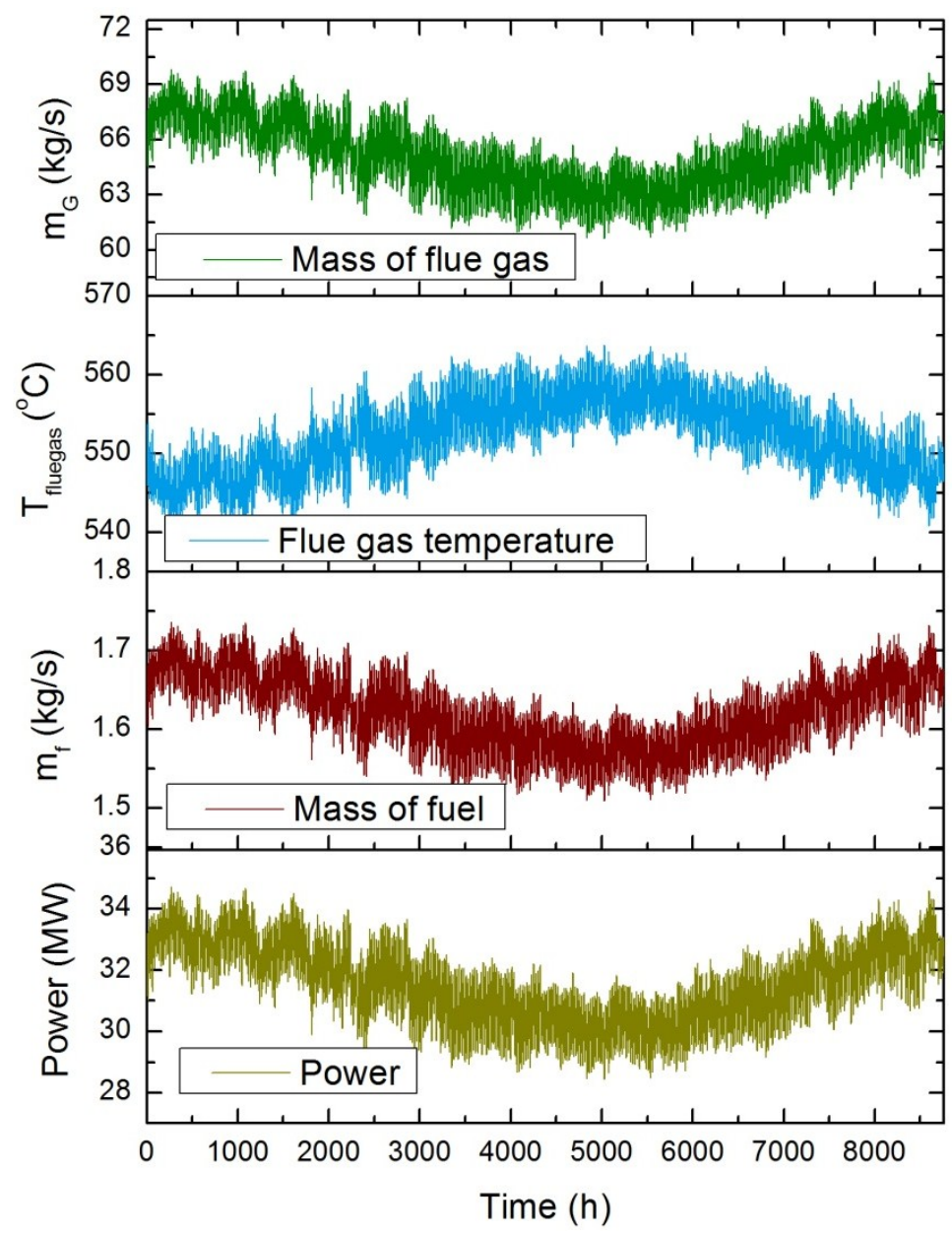




\subsection{Steam Cycle}

In HRSG, outlet conditions of the super-heated steam are optimized based on maximum permissible temperature and pressure ranges of the steam turbine. HRSG system is simulated for different inlet conditions of flue gases at feed pressure of 65 bar. Feed water flow rates are optimized for secure operation of steam cycle. Limiting the temperature of super-heated steam below the maximum acceptable temperature limit of the steam turbine is considered as the optimization criterion. Maintaining constant feed water flow rate in the steam cycle allows uniform heat recovery to drive cooling and desalination cycles throughout the year. $Q-T$ profile of HRSG for the design conditions in the month of July is shown in Figure 7. HRSG is simulated with a constant approach temperature and pinch point difference of $10 \mathrm{~K}$. Steam turbine is selected based on design conditions and requirements. The parameters of the steam turbine are shown in Table 3.

Figure 7. $Q-T$ profile of HRSG in July.

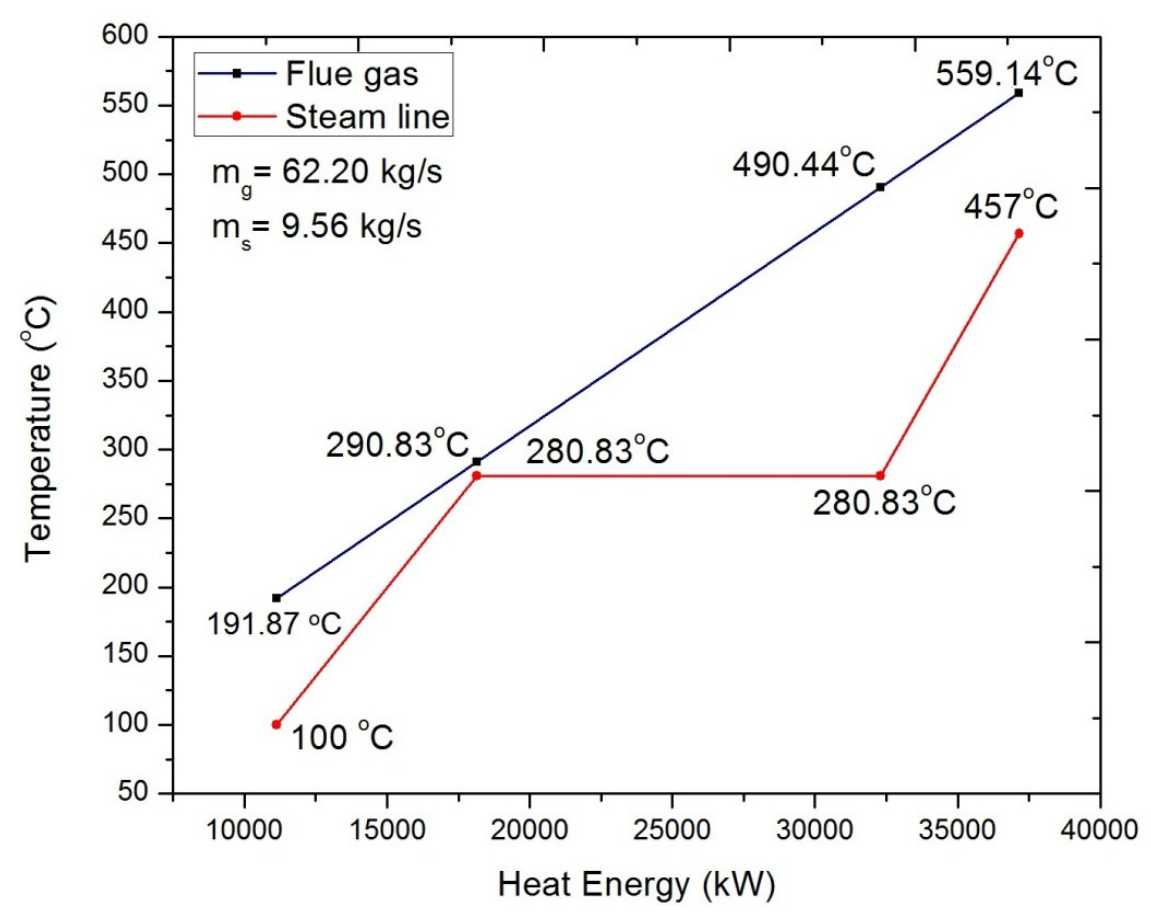

Table 3. Technical specifications of steam turbine [20] (Copyright 2014 Siemens AG).

\begin{tabular}{ccc}
\hline No. & Description & Parameters \\
\hline 1 & Steam turbine model (Siemens) & SST-100 \\
2 & Power output & $8.5 \mathrm{MW}$ \\
3 & Inlet steam pressure & $\mathrm{Up} \mathrm{to} 65 \mathrm{bar}$ \\
4 & Inlet steam temperature & $\mathrm{Up} \mathrm{to} 480{ }^{\circ} \mathrm{C}$ \\
5 & Condensing pressure & $1 \mathrm{bar}$ \\
6 & Exhaust area & $0.22 \mathrm{~m}^{2}$ \\
\hline
\end{tabular}

The performance of the steam cycle in the tri-generation system is analyzed for the variations of air intake temperatures. The system is simulated for different inlet conditions of flue gases as shown in Figure $8 \mathrm{a}$. The electricity production and stack temperature of flue gases leaving the HRSG are chosen as 
the prime indicative parameters in this study. The electricity production in steam power cycle follows a similar trend as the gas power cycle. Reduction in the quantity of flue gases at higher air intake temperature is the major influencing factor for the decreasing trend of power production. Energy balance in the economizer indicates that the stack temperature decreases with reduction in the mass-flow rate of flue gases. Annual performance of steam cycle is shown in Figure $8 \mathrm{~b}$. The performance of the steam cycle improves during winter months due to higher mass-flow rate of flue gases.

Figure 8. (a) Performance of steam power cycle for varying inlet temperatures; (b) Annual performance of steam cycle.

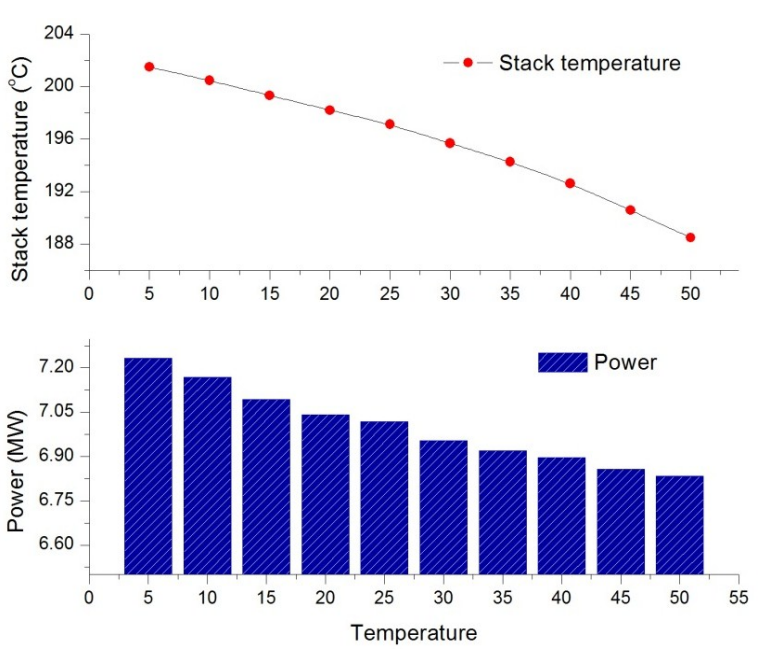

(a)

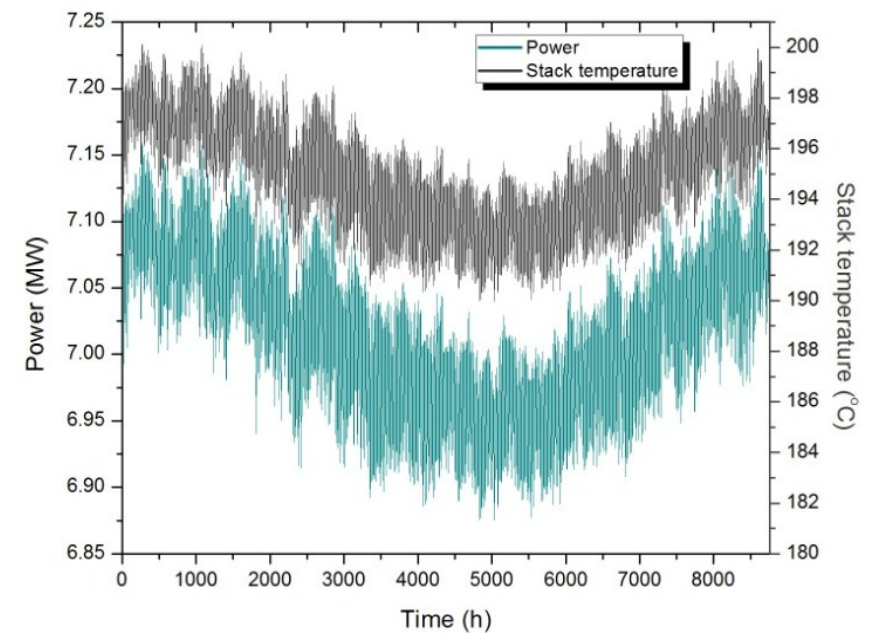

(b)

\subsection{Absorption Chiller}

In the district cooling network, duplex houses in the Al-Hamra region are considered. Duplex houses are two identical houses sharing a common wall with a total floor area of $390 \mathrm{~m}^{2}\left(195 \mathrm{~m}^{2}\right.$ for single house). The cooling load requirement of a duplex house binding the ASHRAE standards is estimated by modeling and simulating the duplex house in TRNBuilt software. The annual cooling load distribution (hourly distribution) for maintaining indoor set point temperature of $22{ }^{\circ} \mathrm{C}$ is shown in Figure 9. The building simulation is conducted with occupancy of five persons per building and infiltration rate of $0.25 \mathrm{ACH}$. The enlarged peak cooling requirement of a duplex building is shown in Figure 9. Cooling energy requirements in the summer reach up to $36.5 \mathrm{~kW}$ for a duplex house, this peak cooling requirement is considered as the design condition for the distribution in the district cooling network. The coefficient of performance (COP) of the chiller varies between 0.75 and 0.69 , as the system is operated with a hot water inlet temperature of $90{ }^{\circ} \mathrm{C}$. The variation in COP is mainly due to the temperature of cold water supplied to the condenser.

Based on the energy balances of the heat recovery system, the total hot sea water production rate is determined to be $358 \mathrm{~kg} / \mathrm{s}$. This can be used to determine the chilling capacity of the absorption chiller. As discussed earlier, the peak load requirement is considered as the design parameter for sizing the distribution network. Performance of the absorption chiller plant during the peak load period with varying inlet hot water temperatures is shown in Figure 10a. The chilled energy production of the absorption chiller maximizes at higher temperatures. At the supply temperature of $90{ }^{\circ} \mathrm{C}, 4621.69 \mathrm{~kW}$ 
of chilled energy is produced. It is sufficient to meet the cooling demands of 124 duplex villas as the peak cooling demand per villa is $36.5 \mathrm{~kW}$ with a COP of 0.69 . Reduction in the inlet hot water temperature by $10{ }^{\circ} \mathrm{C}$ affects the performance of chiller by $39 \%$; steep decrease in performance of absorption chiller is observed with reduction in supply temperature. Operation of the absorption chiller is optimized based on the cooling demand requirements of the building. Month-wise cooling energy production by the absorption chiller is shown in Figure 10b. The production maximizes in the month of July as it corresponds to the cooling energy peak demand.

Figure 9. Annual cooling load in a duplex house.
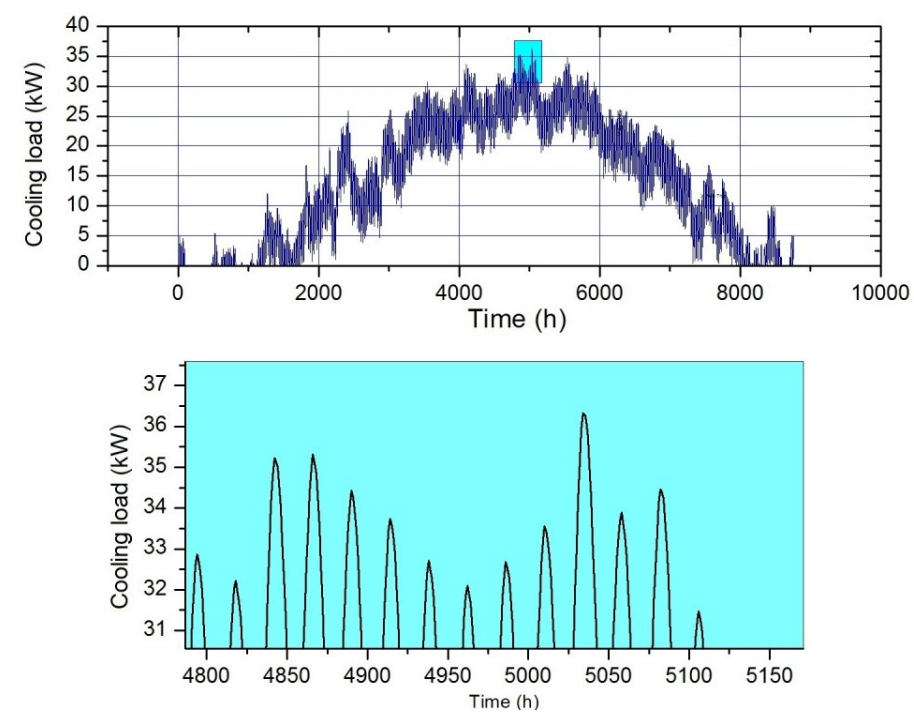

Figure 10. (a) Performance of absorption chiller with varying inlet hot temperature; (b) Month-wise cooling energy production.

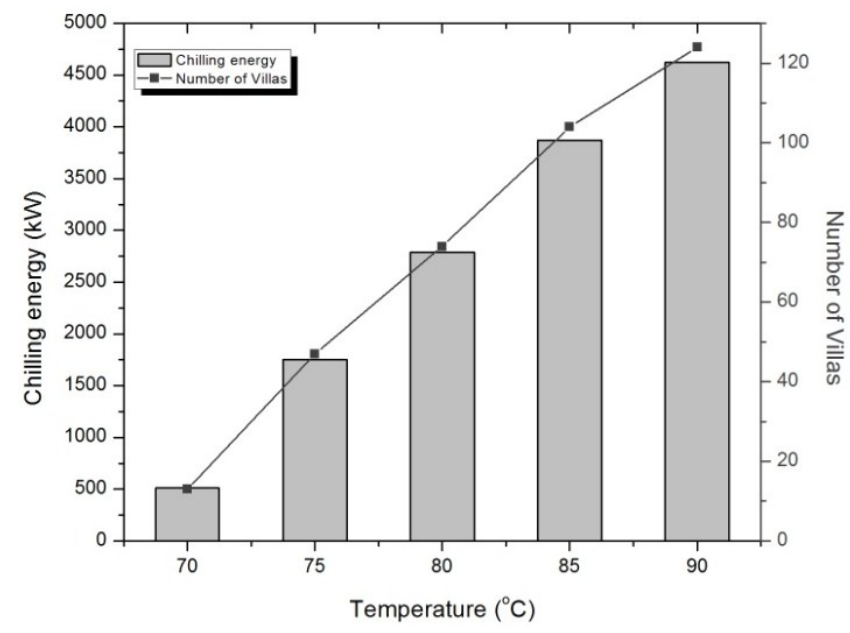

(a)

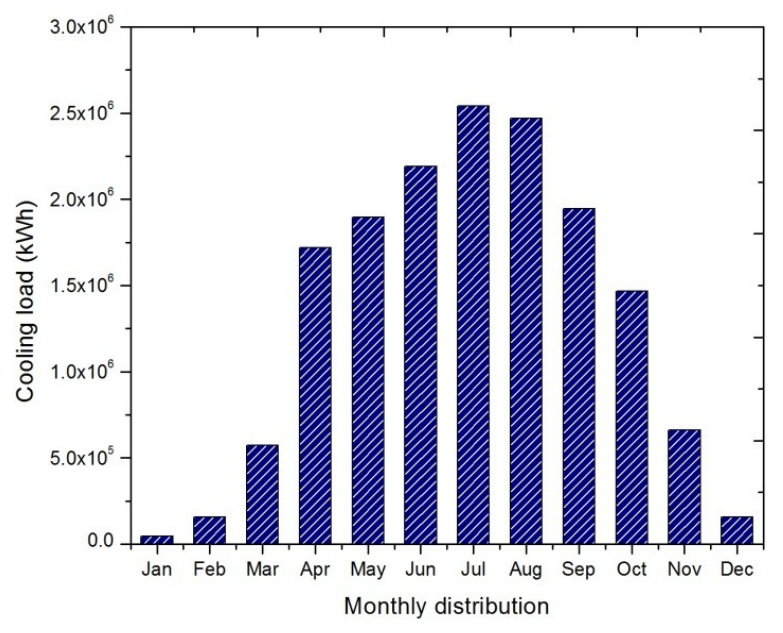

(b)

\subsection{Membrane Distillation}

Performance of two-stage membrane distillation system is evaluated by varying the temperatures of hot and cold sides as shown in Figure 10. The system is simulated for hot side temperatures from 60-90 ${ }^{\circ} \mathrm{C}$ and cold side temperatures between $10{ }^{\circ} \mathrm{C}$ and $50{ }^{\circ} \mathrm{C}$ with an increment of $5{ }^{\circ} \mathrm{C}$ as shown in 
Figure 11. The distillate productivity improves with increase in hot side temperature and decrease in cold side temperature. Maximum distillate productivity of a two-stage system is $41 \mathrm{~kg} / \mathrm{h}$ with hot side temperature of $90^{\circ} \mathrm{C}$ and cold side temperature of $10^{\circ} \mathrm{C}$.

Figure 11. Distillate production for variation in hot and cold side temperatures.

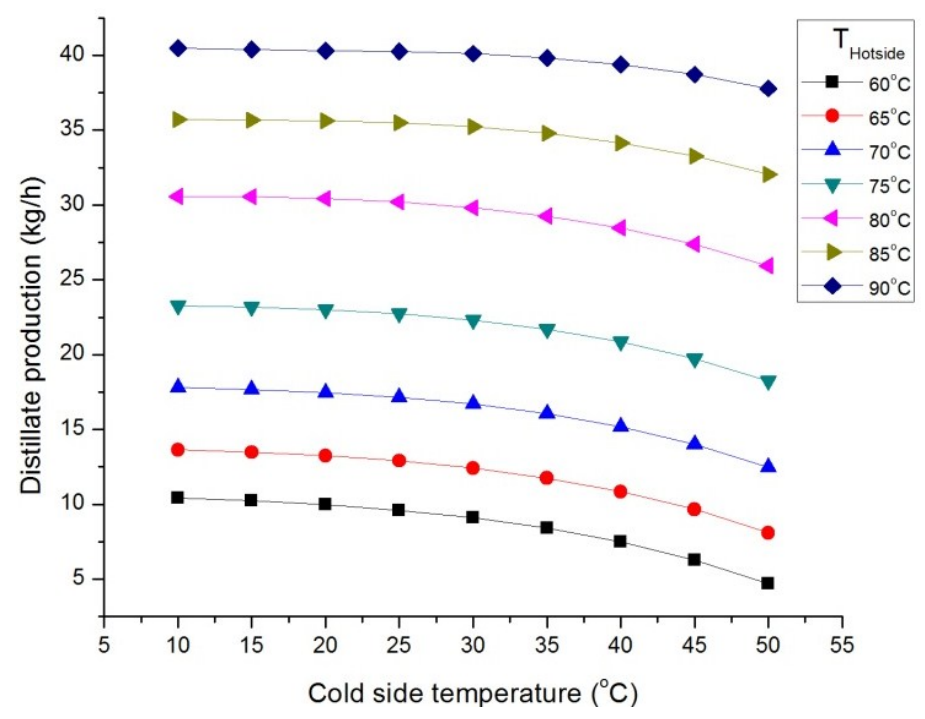

Based on the energy balance in the heat recovery system, a total of 967 multi-effect membrane desalination units can be connected in parallel, each unit containing two membrane modules connected in series. The thermal energy supplied to the membrane distillation plant is optimized based on cooling energy requirements. Year-round dynamic simulation of two-stage membrane distillation plant is conducted, productivity is affected by the cold side temperature and cooling energy demands as shown in Figures 12 and 13. Sea water at ambient temperature is supplied to the cold side of the membrane distillation system. The productivity of desalination plant reduces gradually with increase in cooling energy demand and ambient temperature. Productivity of the plant drops by $12 \%$ in the summer due to higher cooling energy demands and cold side temperatures.

Figure 12. Effect of ambient temperature on distillate production.

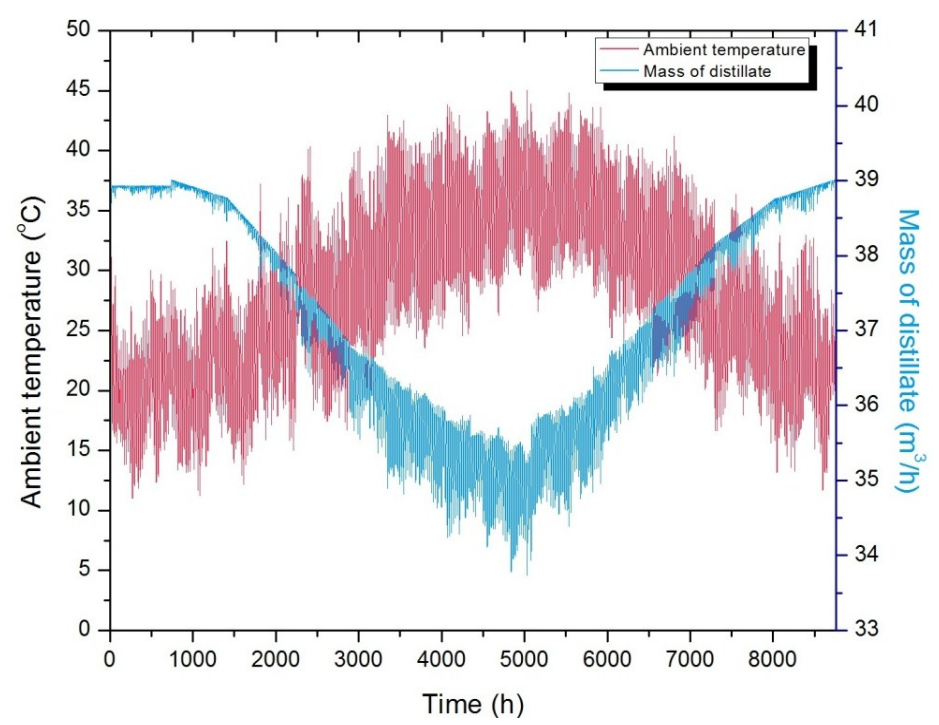


Figure 13. Effect of cooling load on distillate production.

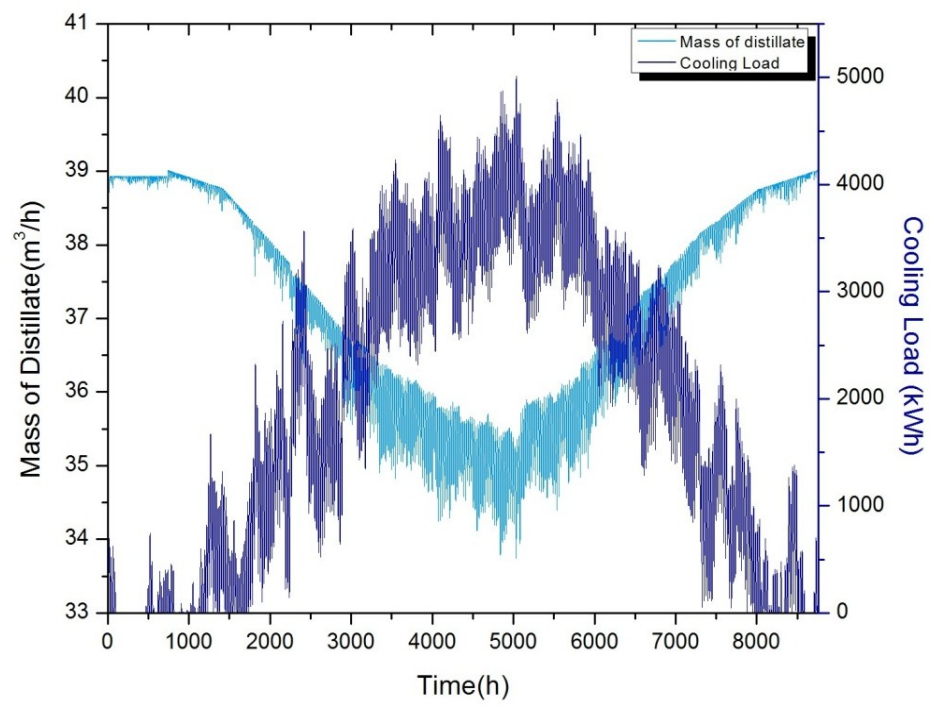

\subsection{Energy Efficiency}

Month-wise energy distribution between different thermal cycles of the tri-generation system is shown in Figure 14a. Useful energy produced by the tri-generation cycle is reduced in the summer months due to higher air intake temperature in the gas cycle leading to lesser fuel consumption. Month-wise energy efficiencies of gas cycle, combined cycle and tri-generation cycle is shown in Figure 14b. The gas cycle efficiency and combined cycle efficiency reduces in summer months due to lower power production, while the efficiency of tri-generation cycle increases by $4 \%$ during this period due to full scale operation of absorption chiller plant as shown in Figure 14b.

Figure 14. (a) Month-wise energy distribution; (b) Annual distribution of cycle efficiencies.

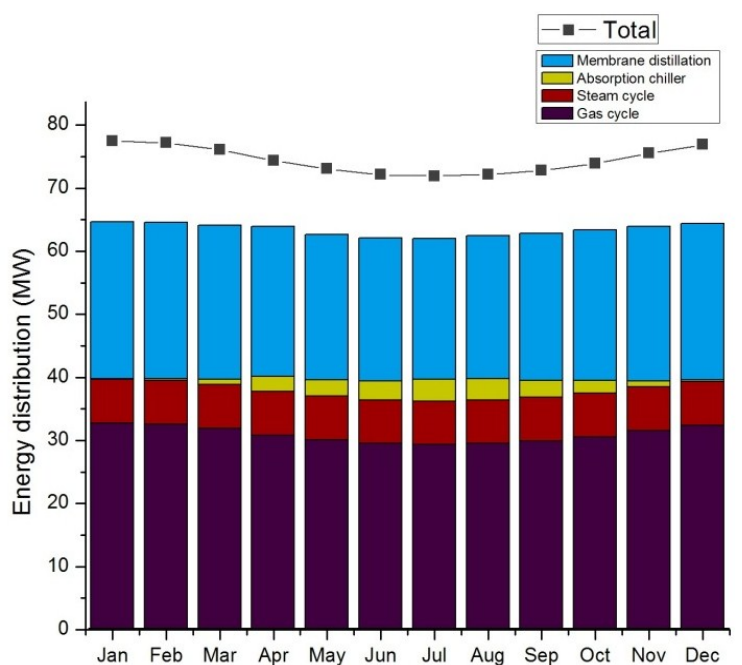

(a)

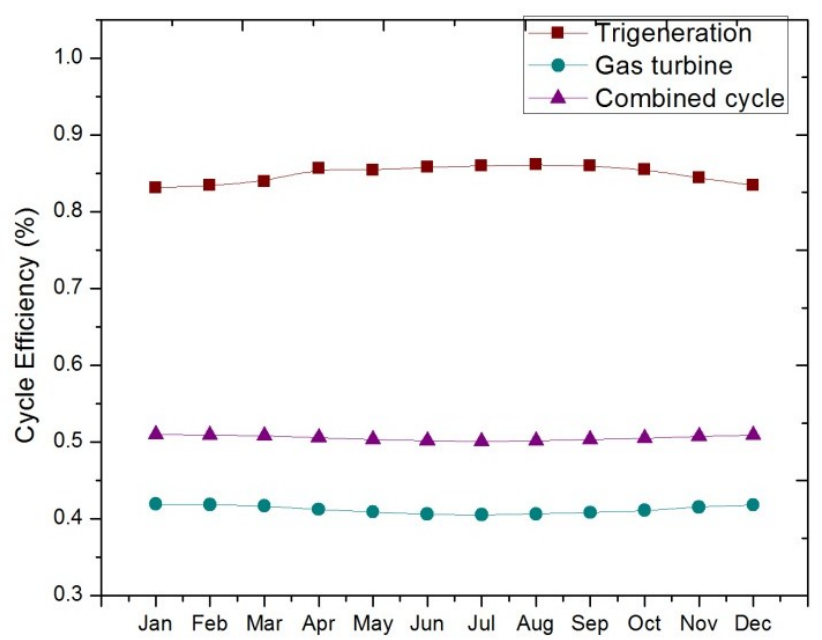

(b)

Energy flows during peak load conditions is represented in sankey diagram as shown in Figure 15. About $25 \%$ of waste heat could not be recovered due to sulfur condensation issues, major part of waste heat is been utilized for production of the fresh water. 
Figure 15. Sankey diagram of energy flows.
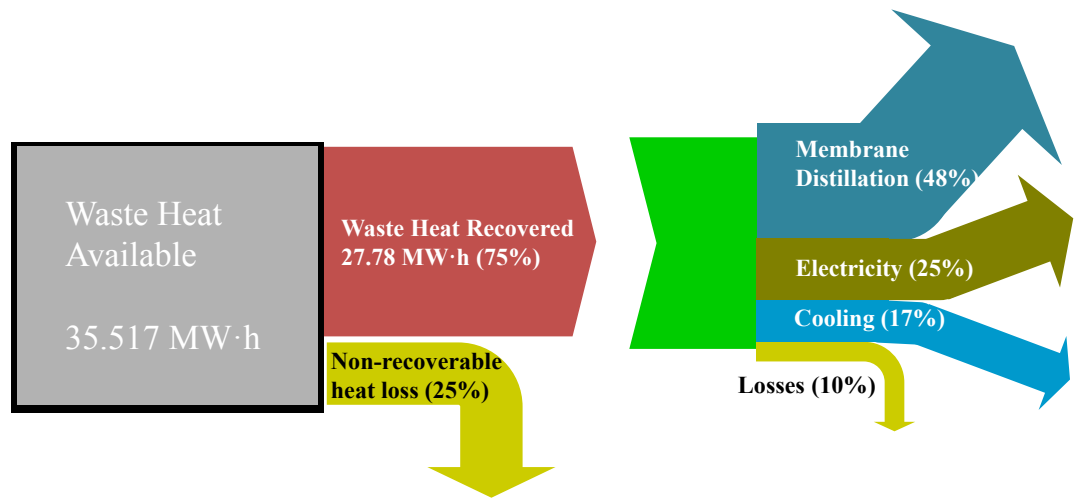

\subsection{Emission Analysis}

Along with the energy benefits in terms of high thermal efficiencies, the tri-generation system also has the potential to reduce greenhouse gas emissions. Normalized emission of $\mathrm{CO}_{2}$ and $\mathrm{NO}_{x}$ per $\mathrm{MW} \cdot \mathrm{h}$ is reduced by implementing poly-generation cycles. Variations of emissions for all three cycles-gas cycle, combined power cycle and tri-generation cycle - are shown in Figure 16. The $\mathrm{CO}_{2}$ coefficient emission per $\mathrm{kW} \cdot \mathrm{h}$ of electricity production is utilized for determining annual $\mathrm{CO}_{2}$ emissions. $\mathrm{CO}_{2}$ emission coefficient for $\mathrm{UAE}$ is $600 \mathrm{~g}$ of $\mathrm{CO}_{2}$ per $\mathrm{kW} \cdot \mathrm{h}$ of electricity production [21]. Normalized $\mathrm{CO}_{2}$ emission of tri-generation system reduces by $51.5 \%$, which proves the environmental sustainability of the system. This reduction in normalized $\mathrm{CO}_{2}$ emission is achieved through total $\mathrm{CO}_{2}$ avoided by driving the tri-generation system using waste heat recovery. In tri-generation scenario, production has been increased by $51.5 \%$ with same amount of fuel usage leading to lower carbon emission. Along with $\mathrm{CO}_{2}$, other GHG emissions like $\mathrm{NO}_{x}, \mathrm{SO}_{x}$ emissions were also reduced by $51.5 \%$. In UAE, $\mathrm{NO}_{x}$ contribute to $5 \%$ of total GHG emissions which leads to normalized production of $38 \mathrm{~g}$ per $\mathrm{kW} \cdot \mathrm{h}$ [22]. With tri-generation, the $\mathrm{NO}_{x}$ emissions are reduced to $18.4 \mathrm{~g} \mathrm{per} \mathrm{kW} \cdot \mathrm{h}$. Total $\mathrm{CO}_{2}$ and $\mathrm{NO}_{x}$ emissions of the existing gas turbine power plant is estimated by:

Total emissions $=$ emission coefficient $\times$ Annual electricity production

Figure 16. Normalized $\mathrm{CO}_{2}$ and $\mathrm{NO}_{x}$ emissions.

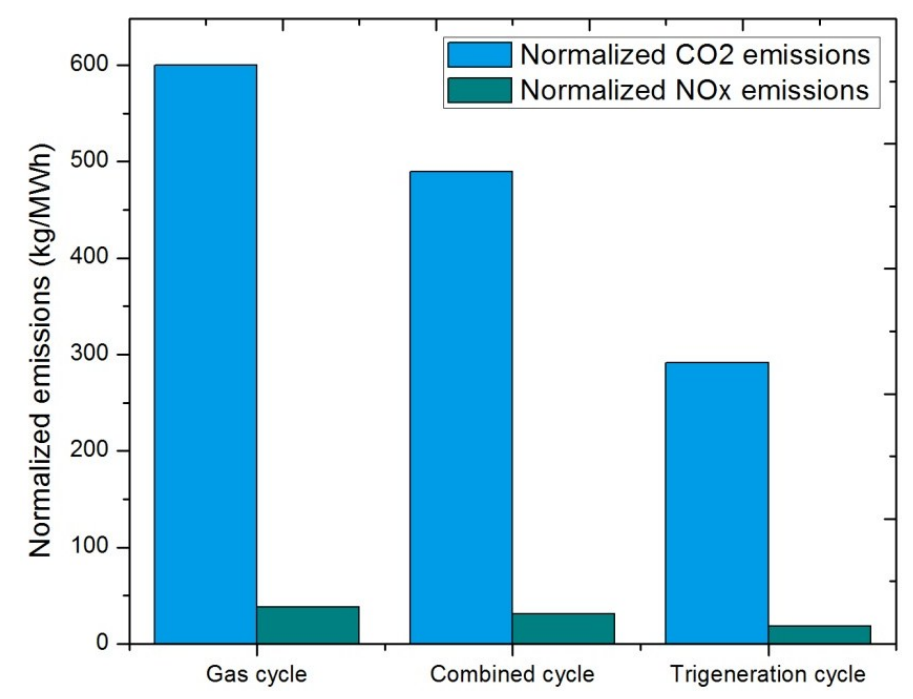




\subsection{Economic Analysis}

Economic benefit of implementing the tri-generation system for the waste heat recovery is discussed in this section. Lower operating costs are achieved in the tri-generation system as waste heat is utilized in the complete operation. The cost of individual components and other necessary parameters are shown in Table 4. Total investment, operation and maintenance costs and annual benefits are estimated as shown in Table 5.

Table 4. Parameter and costs required for economic analysis.

\begin{tabular}{ccc}
\hline Component & Abbreviation & Value \\
\hline Heat recovery steam generator [23] & $C_{\mathrm{HRSG}}$ & Equation (33) \\
Steam turbine [23] & $C_{\mathrm{ST}}$ & Equation (37) \\
Heat recovery unit [24] & $C_{\mathrm{HRS}}$ & $\$ 2,000 / \mathrm{m}^{2}$ \\
Feed water pump (Steam cycle) [25] & $C_{\mathrm{ST}, \mathrm{PUMP}}$ & $881 \mathrm{~W}_{\mathrm{p}}^{0.4}$ \\
Membrane distillation unit [26] & $C_{\mathrm{AGMD}}$ & $\$ 1,375 / \mathrm{unit}$ \\
Membrane replacement cost [24] & $C_{\mathrm{MD}, \mathrm{R}}$ & $15 \%$ of $\mathrm{C}_{\mathrm{AGMD}}$ \\
Feed pump (Heat recovery) [25] & $C_{\mathrm{HRS}, \mathrm{PUMP}}$ & $881 \mathrm{~W}_{\mathrm{p}}{ }^{0.4}$ \\
Absorption chiller [27] & $C_{\mathrm{AC}}$ & $\$ 400 / \mathrm{kW}$ \\
Hydraulics [26] & $C_{\mathrm{HYD}}$ & $5 \%$ of component costs \\
Installation cost [26] & $C_{\mathrm{I}}$ & $5 \%$ of component costs \\
Interest rate & $i$ & $10 \%$ \\
Life time of the project & $n$ & $20 \mathrm{years}$ \\
Cost of electricity & $C_{\mathrm{F}}$ & $\$ 0.12 / \mathrm{kW} \cdot \mathrm{h}$ \\
\hline
\end{tabular}

Table 5. Economic analysis of tri-generation system.

\begin{tabular}{ccc}
\hline No. & Parameters & Values \\
\hline 1 & Investment cost & $\$ 11,079,548$ \\
2 & Operating and maintenance cost & $\$ 443,494$ \\
3 & Annual benefits & $\$ 9,413,460$ \\
4 & Payback period & 1.38 years \\
5 & Net present value & $\$ 66,102,281$ \\
\hline
\end{tabular}

The cumulative net present value (NPV) and payback period (PB) of the tri-generation system are evaluated and shown in Table 5. Annual benefits by implementing tri-generation are estimated based on total annual production of electricity, cooling and freshwater as shown in Table 6. The net present value for the project is estimated by:

$$
N P V=-C_{\mathrm{O}}+(B-C)\left[\frac{(1+i)^{n}-1}{i(1+i)^{n}}\right]
$$

where $C_{0}$ is the total investment $\operatorname{cost} ; B$ is the annual benefits; $C$ is annual operation and maintenance cost; $i$ is the interest rate and $n$ is the life time of the project. The payback period of the project is determined by:

$$
P B=\frac{\ln (B-C)-\ln \left[(B-C)-i C_{\mathrm{O}}\right]}{\ln (1+i)}
$$


The investment of HRSG and steam turbine are determined by [23]:

$$
\begin{gathered}
C_{\mathrm{HRSG}}=4131.8\left(f_{\mathrm{p}} \cdot f_{\mathrm{T}, \text { steam }} \cdot f_{\mathrm{T}, \mathrm{gas}}\left(\frac{Q}{\Lambda T_{\mathrm{ln}}}\right)^{0.8}\right)+13380\left(f_{\mathrm{p}} \cdot \dot{m}_{\text {steam }}\right)+1489.7 \dot{m}_{\mathrm{gas}}^{1.2} \\
f_{\mathrm{p}}=0.0971 \frac{P \mathrm{r}}{30 \mathrm{bar}}+0.9029 \\
f_{\mathrm{T}, \text { steam }}=1+\exp \left(\frac{T_{\text {out }, \text { steam }}-830}{500}\right) \\
f_{\mathrm{T}, \mathrm{gas}}=1+\exp \left(\frac{T_{\text {out }, \text { gas }}-990}{500}\right) \\
C_{\mathrm{ST}}=3880.5 P_{\mathrm{ST}}^{0.7}\left(1+\left(\frac{0.05}{1-\eta_{\mathrm{ST}}}\right)^{3}\right) \cdot\left(1+5 \exp \left(\frac{T_{\mathrm{in}}-866}{10.52}\right)\right)
\end{gathered}
$$

where $Q$ is the heat transfer in HRSG; $\Lambda T_{\mathrm{ln}}$ is temperature difference across HRSG and $\operatorname{Pr}$ is the pressure of feed water to the HRSG. The total investment of cost $\left(C_{0}\right)$ of the project is calculated by:

$$
\begin{aligned}
C_{\mathrm{O}}= & C_{\mathrm{HRSG}}\left(P_{\mathrm{HRSG}}\right)+C_{\mathrm{ST}}\left(P_{\mathrm{ST}}\right)+C_{\mathrm{HRS}}\left(A_{\mathrm{HRS}}\right)+C_{\mathrm{ST}, \mathrm{PUMP}}\left(P_{\mathrm{ST}, \mathrm{PUMP}}\right) \\
& +C_{\mathrm{AGMD}}\left(N_{\mathrm{AGMD}}\right)+C_{\mathrm{HRS}, \mathrm{PUMP}}\left(P_{\mathrm{HRS}, \mathrm{PUMP}}\right)+C_{\mathrm{AC}}\left(P_{\mathrm{AC}}\right)+C_{\mathrm{HYD}}
\end{aligned}
$$

$P_{\mathrm{HRSG}}, P_{\mathrm{ST}}, P_{\mathrm{ST}, \mathrm{PUMP}}$ and $P_{\mathrm{HR}, \mathrm{PUMP}}$ are the total capacity of $\mathrm{HRSG}$, steam turbine and feed pumps of the steam cycle and the heat recovery system. AHRS is the area of the heat recovery system and $N_{\text {AGMD }}$ is the number of membrane distillation modules. The annual operation and maintenance cost for tri-generation project includes electricity requirements for the feed pumps and membrane replacement charges.

Table 6. Annual benefits.

\begin{tabular}{ccc}
\hline Parameters & Value & Total benefits \\
\hline Electricity production & $\$ 0.12 / \mathrm{kW} \cdot \mathrm{h}$ & $\$ 7,289,423.73$ \\
Cooling benefits & $\$ 0.10 / \mathrm{kW} \cdot \mathrm{h}$ & $\$ 1,582,854.46$ \\
Cooling demand charges & $\$ 42.3 / \mathrm{kW} \cdot$ year & $\$ 211,500.00$ \\
Water production cost & $\$ 1 / \mathrm{m}^{3}$ & $\$ 329,681.90$ \\
\hline
\end{tabular}

The share of different equipment costs involved in the total investment is shown in Figure 17. Investment costs of membrane distillation unit and steam turbine account for close to $46 \%$ of the total investment cost.

In terms of current fuel cost in the region, the system has a short payback of 1.38 years and greater cumulative profit of $\$ 66.10$ million. Economic analysis with the possibility of changes in electricity prices is shown in Figure 18. The annual cash flows of the project are simulated with an interest rate of $10 \%$ as shown in Figure 19. The cash flow decreases with number of years as the present worth factor is considered. 
Figure 17. Distribution of investment cost.

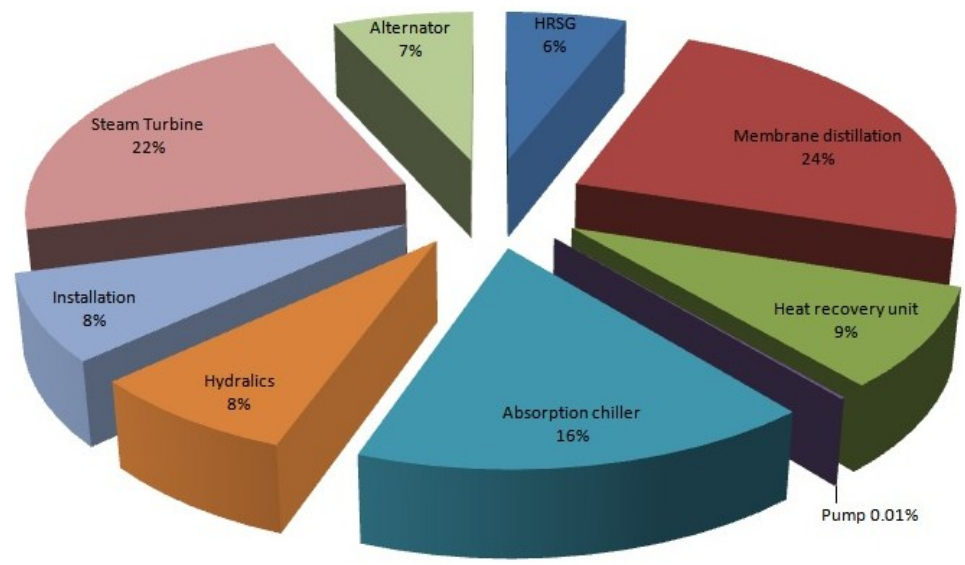

Figure 18. Economic analysis for tri-generation system.

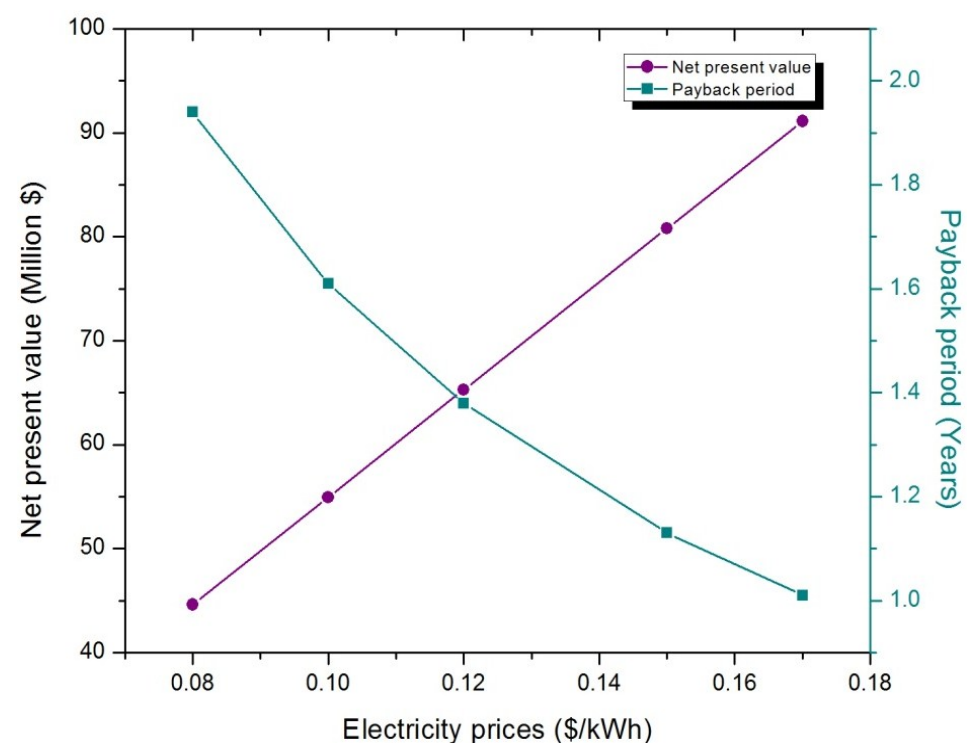

Figure 19. Cash flows of tri-generation system.

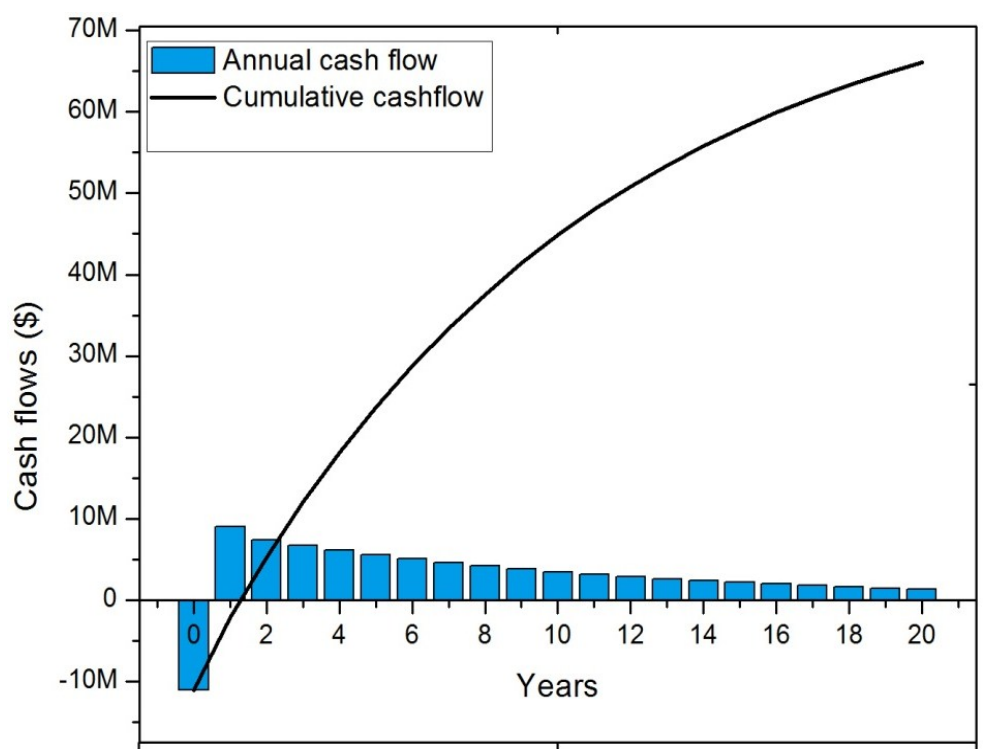




\section{Conclusions}

A tri-generation system based on the integration of power, cooling and desalination thermal cycles was presented. A detailed numerical case study was developed for the implementation in Al-Hamra area, Ras Al Khaimah, UAE. The tri-generation system is modeled for maximizing the utilization of waste heat by driving four thermal cycles based on quality and temperature of thermal energy. The absorption chiller plant is optimized based on cooling energy requirement of duplex villas in the region. The simulation results show that energetic efficiency of tri-generation system is maximized by up to $85 \%$ in summer due to lower fuel consumption and full scale operation of absorption chiller. The thermal cycle performances are largely affected by air intake temperature, but due to the lower cooling requirement in winter, the overall thermal efficiency reduces with lower air intake temperatures. Other important conclusions drawn from the project of recovering waste heat from existing power plants are as follows:

- The absorption chiller plant can provide district cooling for 124 duplex houses with a production capacity of $4600 \mathrm{~kW}$ during peak requirements;

- The production capacity of membrane distillation plant varies between 33 and $37 \mathrm{~m}^{3} / \mathrm{h}$ based on daily cooling requirements and ambient temperature;

- The normalized $\mathrm{CO}_{2}$ emission per $\mathrm{MW} \cdot \mathrm{h}$ is reduced to $291 \mathrm{~kg} / \mathrm{MW} \cdot \mathrm{h}$ from an actual scenario of $600 \mathrm{~kg} / \mathrm{MW} \cdot \mathrm{h}$ by implementation of the waste heat recovery system;

- In terms of economy, the system has a rapid payback period of 1.38 years with a cumulative saving of $\$ 66$ million.

\section{Acknowledgments}

The authors would like to extend their gratitude to the Ras Al Khaimah Investment Authority for their financial support and Al-Hamra gas turbine power plant for the technical cooperation. Special thanks to KTH Royal Institute of technology, Stockholm for the fruitful cooperation in the project.

\section{Nomenclature}

$\begin{array}{ll}A & \text { Area }\left(\mathrm{m}^{2}\right) \\ A G M D & \text { Air gap membrane distillation } \\ B & \text { Benefits }(\$) \\ C_{P} & \text { Specific heat capacity }(\mathrm{kJ} / \mathrm{kg} \cdot \mathrm{K}) \\ C C H P & \text { Combined cooling, heat and power } \\ C H P & \text { Combined heat and power cycle } \\ E & \text { Energy flux }(\mathrm{kJ}) \\ N P V & \text { Net present value }(\$) \\ \text { GHG } & \text { Greenhouse gases } \\ K & \text { Thermal conductivity }(\mathrm{W} / \mathrm{m} \cdot \mathrm{K}) \\ L H V & \text { Lower heating value } \\ M E N A & \text { Middle East and North Africa } \\ P & \text { Power capacity }(\mathrm{kW}) \\ P B & \text { Payback period }(\text { years })\end{array}$




$\begin{array}{ll}Q & \text { Heat energy }(\mathrm{kJ}) \\ S & \text { Entropy }(\mathrm{kJ} / \mathrm{kg} \cdot \mathrm{K}) \\ U & \text { Overall heat transfer coefficient } \\ X & \text { Mole fraction of water vapor } \\ A C H & \text { Air changes per hour } \\ B & \text { Membrane thickness }(\mathrm{mm}) \\ C & \text { Cost }(\$) \\ C C & \text { Combustion chamber } \\ C C C W P & \text { Combined cooling, clean water and power } \\ C O P & \text { Coefficient of performance } \\ H R S G & \text { Heat recovery steam generator } \\ I & \text { Interest rate }(\%) \\ H & \text { Enthalpy }(\mathrm{kJ} / \mathrm{kg}) \\ L & \text { Air gap width }(\mathrm{mm}) \\ M & \text { Mass flow }(\mathrm{kg} / \mathrm{h}) \\ \dot{m} & \text { mass flow rate }(\mathrm{kg} / \mathrm{s}) \\ P & \text { Partial pressure of vapor } \\ P r & \text { Pressure }(\mathrm{bar}) \\ R H & \text { Reheat chamber } \\ T & \text { Temperature }\left({ }^{\circ} \mathrm{C}\right) \\ V A C & \text { Vapor absorption chiller } \\ & \end{array}$

\section{Greek Letters}

$\begin{array}{ll}\Delta \mathrm{T} & \text { Change in temperature } \\ \lambda_{L} & \text { Latent heat of evaporation } \\ \Gamma & \text { Specific heat ratio } \\ \Phi & \text { Porosity } \\ \mathrm{H} & \text { Efficiency }\end{array}$

\section{Subscripts}

$\begin{array}{ll}\text { A } & \text { Air } \\ \text { C } & \text { Cold side } \\ \text { Ch } & \text { Chilled water } \\ \text { F } & \text { Fuel } \\ \text { Gen } & \text { Generator } \\ \text { H } & \text { Hot side } \\ \text { LMTD } & \text { Logarithmic mean temperature difference } \\ \text { RH } & \text { Reheat chamber } \\ \text { ST } & \text { Steam turbine } \\ \text { T } & \text { Thermal } \\ \text { Ac } & \text { Absorption chiller }\end{array}$




$\begin{array}{ll}\text { Cc } & \text { Combustion chamber } \\ \text { Dis } & \text { Distillate } \\ \text { G } & \text { Gas } \\ \text { GT } & \text { Gas turbine } \\ \text { HRS } & \text { Heat recovery system } \\ \text { MD } & \text { Membrane distillation } \\ \text { Stack } & \text { Stack temperature } \\ \text { SW } & \text { Seawater } \\ \text { Tri } & \text { Tri-generation }\end{array}$

\section{Author Contributions}

All the authors contributed in different ways during progress of the research work. Gowtham Mohan designed and simulated the waste heat recovery system with guidance of Sujata Dahal and Uday kumar. Sujata dahal developed the numerical codes for membrane distiller models. Andrew Martin verified the results and manuscript. Hamid kayal involved in verification of economics and managed the resources.

\section{Conflicts of Interest}

The authors declare no conflict of interest.

\section{References}

1. Kong, X.Q.; Wang, R.Z.; Huang, X.H. Energy optimization model for a CCHP system with available gas turbines. Appl. Therm. Eng. 2005, 80, 377-391.

2. Khan, K.H.; Rasul, M.G.; Khan, M.M.K. Energy conservation in buildings: Cogeneration and cogeneration coupled with thermal-energy storage. Appl. Therm. Eng. 2004, 77, 15-34.

3. Havelsky, V. Energetic efficiency of cogeneration system for combined heat, cold and power production. Int. J. Refrig. 1999, 22, 479-485.

4. Bilgen, E. Exergetic and engineering analyses of gas turbine based cogeneration systems. Energy 2000, 25, 1215-1229.

5. Huangfu, Y.; Wu, J.Y.; Wang, R.Z.; Kong, X.Q.; Wei, B.H. Evaluation and analysis of novel micro-scale combined cooling, heating and power (MCCHP) system. Energy Convers. Manag. 2007, 48, 1703-1709.

6. Liu, M.; Shi, Y.; Fang, F. Combined cooling, heating and power systems: A survey. Renew. Sustain. Energy Rev. 2014, 35, 1-22.

7. Ahmadi, P.; Dincer, I.; Rosen, M.A. Exergo-environmental analysis of an integrated organic Rankine cycle for trigeneration. Energy Convers. Manag. 2012, 64, 447-453.

8. Khaliq, A. Exergy analysis of gas turbine trigeneration system for combined production of power heat and refrigeration. Int. J. Refrig. 2009, 32, 534-545.

9. Ahmadi, P.; Rosen, M.A.; Dincer, I. Greenhouse gas emission and exergo-environmental analyses of a trigeneration energy system. Int. J. Greenh. Gas Control 2011, 5, 1540-1549. 
10. Temir, G.; Bilge, D. Thermoeconomic analysis of a trigeneration system. Appl. Therm. Eng. 2004, 24, 2689-2699.

11. Sun, Z.G. Energy efficiency and economic feasibility analysis of cogeneration system driven by gas engine. Energy Build. 2008, 40, 126-130.

12. Hussain, H.J. Development of a Hybrid Powerplant for Kuwait: The Simultaneous Production of Power, Fresh Water and Cooling. Ph.D. Thesis, Cranfield University, Shrivenham, UK, 2010.

13. Calise, F.; d'Accadia, M.D.; Piacentino, A. A novel solar trigeneration system integrating PVT (photovoltaic/thermal collectors) and SW (Seawater) desalination: Dynamic simulation and economic assessment. Energy 2014, 67, 129-148.

14. Kullab, A.; Martin, A. Membrane distillation and applications for water purification in thermal cogeneration plants. Sep. Purif. Technol. 2011, 76, 231-237.

15. Liu, C. Polygeneration of Electricity, Heat and Ultrapure Water for the Semiconductor Industry. Master's Thesis, KTH Royal Institute of Technology, Stockholm, Sweden, 2004.

16. Kullab, A. Desalination using Membrane Distillation: Experimental and Numerical study. Ph.D. Thesis, KTH Royal Institute of Technology, Stockholm, Sweden, 2011.

17. Burrieza, E.G.; Blanco, J.; Zaragoza, G.; Alarcón, D.C.; Palenzuela, P.; Ibarra, M.; Gerjak, W. Experimental analysis of an air gap membrane distillation solar desalination pilot plant system. J. Membr. Sci. 2011, 379, 386-396.

18. RAK Property Services. Available online: http://www.rakps.com (accessed on 2 June 2014).

19. Data Sheet of Test Results-GE Energy; Al-Hamra Gas Turbine Powerplant: Ras Al Khaimah, UAE. Unpublished work, 2014.

20. Technical Specification of Steam Turbine SST-100. Available online: http://www.energy.siemens.com (accessed on 25 April 2014).

21. International Energy Agency (IEA) STATISTICS 2012. $\mathrm{CO}_{2}$ Emissions from Fuel Combustion. Available online: http://www.iea.org (accessed on 5 May 2014).

22. Greenhouse Gas Inventory for Abu Dhabi Emirate: Inventory Results Executive Summary; Environment Agency_Abu Dhabi: Abu Dhabi, UAE, 2012.

23. Roosen, P.; Uhlenbruck, S.; Lucas, K. Pareto optimization of a combined cycle power system as a decision support tool for trading off investment vs. operating cost. Int. J. Therm. Sci. 2003, 42, 553-560.

24. Al-Obaidani, S.; Curcio, E.; Macedonio, F.; Profio, G.D.; Al-Hinai, H.; Drioli, E. Potential of membrane distillation in seawater desalination: Thermal efficiency, sensitivity and cost estimation. J. Membr. Sci. 2008, 323, 85-98.

25. Alili, A.A.; Islam, M.D.; Kubo, I.; Hwang, Y.; Radermacher, R. Modeling of a solar powered absorption cycle for Abu Dhabi. Appl. Energy 2012, 93, 160-167.

26. Performance and Cost Estimations of Final Industrial Size of MEDESOL-2 Technology 2010; University of La Laguna: Canary Islands, Spain, 2010.

27. Lazzarin, R.M. Solar cooling: PV or thermal? A thermodynamic and economic analysis. Int. J. Refrig. 2014, 39, 38-47.

(C) 2014 by the authors; licensee MDPI, Basel, Switzerland. This article is an open access article distributed under the terms and conditions of the Creative Commons Attribution license (http://creativecommons.org/licenses/by/4.0/). 